\title{
Social engagement and stock market participation
}

Frederick K. Changwony ${ }^{1,2}$, Kevin Campbell ${ }^{2}$, and Isaac T. Tabner ${ }^{2}$

${ }^{1}$ School of Business and Economics, Moi University and ${ }^{2}$ Stirling Management School, University of Stirling.

\section{Abstract}

We investigate the separate and joint influences of social engagement measures on stock market participation and find that socially engaged individuals are more likely to participate. Consistent with Granovetter's (1973) theory of social networks we find that a weak tie (measured by social group involvement) has a positive effect on stock market participation whereas a strong tie (measured by frequency of talking to neighbours) has no effect. More trusting individuals are more likely to participate in the stock market, as are those who identify with a political party. In contrast, the degree to which religion is important appears to have little impact.

JEL classification: A13, D12, D72, G11, Z12

Keywords: stock market participation, social engagement, household finance.

Acknowledgements: Frederick Changwony is a Commonwealth Scholar funded by the UK Government and is grateful to the Commonwealth Scholarship Commission and Moi University for their financial support. The authors thank Burton Hollified, an anonymous reviewer, Dimitris Georgarakos, David Hillier, Mark Taylor, Mark Bryan, Chris Veld, lan Thomson, Sarah Brown and participants at the $5^{\text {th }}$ International Accounting and Finance Doctoral Symposium held at the University Strathclyde Business School on $19^{\text {th }}-21^{\text {st }}$ June 2012. 


\section{Introduction}

Most households underinvest in stocks despite the long-term risk premium and diversification gains that are available (Mehra and Prescott, 1985). Limited stock market participation has persisted in spite of the growth of stocks held indirectly through vehicles such as mutual funds (Mankiw and Zeldes, 1991; Haliassos and Bertaut, 1995) and it afflicts European as well as US households, albeit to a lesser extent (Guiso et al., 2002). Low stock market participation is evident in our study and the puzzle of persistent low participation is especially concerning at a time when individuals bear more responsibility for investing their money (Campbell et al., 2011).

We assess the extent to which the variety and intensity of an individual's social engagement affects stock market participation. Access to information on how to start investing in the stock market and how to manage a portfolio reduces the fixed costs of stock market participation. Guiso and Japelli (2005) find that greater awareness of stocks, mutual funds and investment accounts is positively correlated with social interaction, while Ivković and Weisbenner (2007) find evidence that local information diffusion leads to common portfolio choices among neighbouring households. Socially engaged households have more opportunities to learn about investment opportunities from peers who are already informed. Over time, social engagement generates a stock of capital, generally referred to as social capital, which reduces information cost barriers to stock market participation. Prior literature suggests that social engagement measures are important determinants of stock market participation (e.g. Hong et al., 2004; Georgarakos and Pasini, 2011; Kaustia and Torstila, 2011). However, most studies investigate these factors in isolation. 
Our study makes four important contributions to the literature. First, we examine information diffusion through two channels of social interaction: frequency of talking to neighbours and involvement in social groups. Although regarded as distinct channels in social interaction theory (Granovetter, 1973) empirical studies assume that they capture the same information (e.g. Hong et al., 2004; Georgarakos and Pasini, 2011). Second, most studies investigate social engagement measures such as trust and religiosity and social group involvement in isolation whereas we bring them together in one model to determine their independent effects. We add to the findings of Georgarakos and Pasini (2011) who combine trust and social group involvement by bringing in religiosity and political identity. Third, we use an integrated measure of political party identification based upon responses to four questions to examine the role of political identity and shifts in political party preferences. Apart from Kaustia and Torstila (2011) and Bonaparte and Kumar (2013) political party identification has not been examined in the context of stock market participation. We extend their analyses by including political identity and shifts in political party preferences, along with other social engagement measures, within the same model. Finally, motivated by the findings in Ai and Norton (2003) and Williams (2012), we interpret our results using marginal effects to show the separate and joint influences of social engagement.

A major factor limiting research on the determinants of stock market participation is a dearth of detailed data (Hong et al., 2004; Georgarakos and Pasini, 2011; Kaustia and Torstila, 2011). We take advantage of data on both individual characteristics and stock market participation available in the British Household Panel Survey (BHPS) across a diverse range of age groups. We use individual level 
data rather than household level data as most of the social engagement variables in the BHPS are derived from individual observations.

Our findings show that both the variety and the intensity of social interaction influence stock market participation. Based on social network theory we measure strong ties using the binary variable talking to neighbours and weak ties using both a binary variable active in social groups and a categorical variable number of social groups. When our set of social engagement measures are analysed in separate equations, all apart from strong ties have significant effects on stock market participation in contrast to the findings of Hong et al. (2004). We conclude that strong ties and weak ties are distinct channels of social interaction. Further, we find that religion has little effect, contrary to the findings of Renneboog and Spaenjers (2012). Our results also indicate that political identity has a separate positive influence on stock market participation. In a specification that includes these variables in one equation, we find that in addition to the independent effects of social group involvement and trust reported in Georgarakos and Pasini (2011) identification with both the Conservative and Liberal Democratic parties have positive effects while religion has a negative effect. ${ }^{1}$ Our results thus indicate that social group involvement, trust, religion and political identity are distinct social engagement measures with independent effects on stock market participation. When we interact these variables, we find that social group involvement and trust compensate for political identity. Further, individuals who have recently identified with the Conservative and Liberal Democratic parties are less likely to participate in the stock

\footnotetext{
${ }^{1}$ When social group involvement is a binary variable, as in prior studies, we find that the variable "religion makes a difference" has a negative and significant effect. When we use our, arguably more robust, categorical measure of social group involvement, "number of social groups", religion ceases to be significant.
} 
market than those who identified with the same party throughout our study, thus indicating a differential effect for consumer voters relative to ideological supporters. The net effect of our social engagement measures is that the probability of stock market participation increases by approximately one fifth for fully engaged individuals compared to those who either do not socially engage or who have few avenues of social engagement.

The rest of the paper proceeds as follows. Section 2 reviews the empirical literature and identifies our social engagement measures. In section 3, we discuss the structure and features of the data, describe the variables and present the descriptive statistics and the research approach. Section 4 presents the empirical results. Finally, we conclude and discuss the implications of the study in section 5 .

\section{Prior literature}

\subsection{Social engagement, social capital and stock market participation}

As individuals interact more with others and become more socially engaged there is reason to believe they will be more inclined to participate in the stock market. For example, those who talk more to their neighbours are more likely to find out about the stock market, as are those who are more involved in social groups. Individuals who are more trusting are more likely to take information they receive about stock market investing at face value and thus be more inclined to participate. Those for whom religious beliefs make more of a difference to their lives are more likely to be socially active in church activities and therefore to be more exposed to the possibility of stock market investing - though their views about the stock market may also be coloured by their interpretation of their religion's perspective on investing. Finally, those who identify themselves with a political party are more likely to encounter 
information about stock market investing through related social activities and stock market participation is likely to be greater if their political beliefs accord with the view that market forces benefit society. In sum, social engagement mechanisms help to reduce information cost barriers that inhibit individuals from participating in the stock market.

Typically, the literature refers not to social engagement but to social capital, which we argue is simply the stock of capital built up over time by the process of social engagement. There is growing evidence that accumulated social capital influences financial well-being. Though there is no consensus on the definition of social capital, much research has been motivated by Putnam (1993) who defines social capital as a combination of trust, norms and networks. These become embedded in individual and group social interactions, enhancing personal and common goals in society (Narayan and Pritchett, 1997; Harper and Kelly, 2003). While there is no general agreement regarding the best social capital metrics, the Social Capital Index composed by Putnam (2000, p. 291) identifies five broad components: (1) community organizational life; (2) engagement in public affairs; (3) community voluntarism; (4) informal sociability; and (5) social trust. ${ }^{2}$ The first four of these components reflect different aspects of social interaction, some of which are fostered by adherence to religious beliefs, while trust arises from the process of repeated social interaction (Putnam, 1995). These dimensions of accumulated social capital - social interaction, trust, and religion - are used in prior studies of stock market participation.

\footnotetext{
${ }^{2}$ Alternative measures of social capital have been suggested. For example, Woolcock (1998) proposes four dimensions: communitarian, network, institutional and synergy.
} 
Some have argued that Putnam's Social Capital Index overly simplifies the different dimensions of social capital. For example, Bjørnskov (2006) suggests investigating the different dimensions individually. In our study we investigate five forms of social engagement: Talking to neighbours (informal sociability); both membership of Social Groups and Religion (community organisational life); Political Party Affiliation (engagement in public affairs) and; Trust (social trust).

\subsection{Social interaction - weak ties and strong ties}

In line with Granovetter's theory of social networks, investigations of the role of social interaction typically identify two channels of information diffusion: weak ties, i.e. ties with formal and informal organisations, and strong ties, i.e. ties with family, neighbours and close associates (Granovetter, 1973; 1983; 2005). Studies that use proxies for strong ties show that knowing and visiting neighbours (Hong et al., 2004), the likelihood of sharing consumption and investing information with neighbours (Ivković and Weisbenner, 2007; Brown et al., 2008) and living in regions with high participation rates in elections, voting, and blood donation (Guiso et al., 2004) increases the probability of stock market participation. Similarly, weak ties such as involvement in social groups is positively associated with stock market participation (Georgarakos and Pasini, 2011; Brown et al., 2008; Christelis et al., 2010). Although these studies suggest a priori an association between the two channels of information diffusion and stock market participation, Granovetter (1983) argues that weak ties provide productive information and new ideas, which we conjecture are more relevant for stock market participation. In other words, social interaction through both weak ties and strong ties provide avenues for the transmission of costless information about the stock market through word-of-mouth or observational learning (Banerjee, 1992). Individuals can derive satisfaction from discussing market 
trends and patterns with friends (Becker, 1991) and talking to family members, neighbours, colleagues and friends about investing (Nofsinger, 2005). However, weak ties play the role of 'transmitting unique and non-redundant information across otherwise largely disconnected segments of social networks' compared to strong ties (Granovetter, 2005). This suggests that effective transmission of financial information regarding investment opportunities, performance and trends potentially occurs through weak ties.

In this study, we underscore the distinction between the two channels of information diffusion. The hypotheses to be tested are:

Hypothesis 1: Individuals who talk more frequently with their neighbours are more likely to participate in the stock market.

Hypothesis 2: Individuals who are active in social groups are more likely to participate in the stock market.

\subsection{Trust and stock market participation}

In the context of this study trust is the degree to which an individual believes that associates or institutions are likely to fulfil their part of a formal or informal contractual agreement (Guiso et al. 2008). For individuals to participate in the stock market they must trust the entire financial system, including the investment process and the actors involved. In a study using a variety of individual and generalised trust measures across countries, Guiso et al. (2008) find that trust has a positive and statistically significant effect upon direct share ownership, the percentage of risky assets owned, the average rate of stock market participation, and the proportion of wealth invested in stocks (Guiso et al., 2004). However, the use of the 'level of trust' as a measure of social capital is debateable as it may be linked with other factors 
such as religiosity or sociability, making causality hard to determine (Guiso et al., 2004).

In a recent study, Georgarakos and Pasini (2011) include trust and sociability measures in one model and find that both have independent effects on stock market participation. They also find that where trust levels are low, sociability may compensate. El-Attar and Poschke (2011) show that households with low trust levels tend to invest in housing rather than risky financial assets. Investigating the role of religion on household finance, Renneboog and Spaenjers (2012) also find a positive association between religiosity and trust. In a related study, Hong et al. (2004) use church attendance as a proxy for sociability, suggesting that both religious beliefs and social interaction are related. These findings underscore the links between trust, religion, and sociability. In this study, we further test the influence of trust on stock market participation while controlling for other social engagement measures. The hypothesis to be tested is:

Hypothesis 3: Individuals who are more trusting are more likely to participate in the stock market.

\subsection{Religion and stock market participation}

Religion can affect the stock market participation decision as a direct result of theological beliefs or indirectly through its effect on factors such as trust and social interaction. The importance of thrift - being careful with money - is a common feature of religious doctrines (Keister, 2003). The long-term outperformance of stocks compared to other asset classes might therefore be expected to encourage stock market participation among those who have a religious affiliation. Guiso et al. (2003) find that religiosity is associated with a greater emphasis on the importance of thrift across countries, and also with a greater sense of individual responsibility. The 
latter may also incline households to invest in the stock market, given the higher rewards available from stocks in the longer term. Religious households are more likely to leave bequests and therefore to consider longer term planning horizons, which favours stock market participation (Renneboog and Spaenjers, 2012).

Guiso et al. (2003) find that religion has a positive effect on trust towards others, mainly through regular attendance at religious services. They also find that it is positively associated with attitudes that are conducive to free markets. Therefore, religion may increase the likelihood of investing in stocks by raising both interpersonal trust and trust in market mechanisms. Attendance at religious services is also likely to increase social networking, which could positively affect stock market participation through increased opportunities for learning about investment choices; Hong et al. (2004) use a general religiosity measure, "attend church", to proxy for social interaction and find it to be positively associated with stock market participation.

Evidence on the role of religion on financial outcomes is mixed and its effect varies across countries. Using Dutch survey data, Renneboog and Spaenjers (2012) find Catholics to be more risk averse compared to Protestants and those of other religious beliefs and that they are less likely to participate in the stock market. However, the level of significance varies considerably depending on the controls used and the findings are not significant when they bring together all variables in one model. Using church membership and attendance data for a demographically representative sample of the Dutch population, Noussair et al. (2012) report that more religious people are more risk averse but their result is driven more by social aspects of church membership than by the religious beliefs themselves. León and Pfeifer (2013) use German survey data and also find religiously affiliated people to 
be more risk-averse, but they go a step further and consider a context-specific risk attitude, namely financial risk-taking. They discover that Christians are more willing to take financial risks compared to non-religious individuals and that they are more likely to hold risky assets such as stocks. This is consistent with the finding of Halek and Eisenhauer (2001) that Catholics and Jews, although more averse to pure risk, are more tolerant of speculative risk taking.

The lack of consistency in findings across countries and studies about the impact of religion may be due to other characteristics of those holding religious beliefs, including alternative aspects of social capital, as alluded to by Gruber (2005). We test the influence of religion using a general question regarding whether respondents think religion makes a difference in their lives. In line with the direct and indirect arguments suggesting a positive influence of religion on stock market participation, the hypothesis to be tested is:

Hypothesis 4: Religion is positively associated with stock market participation.

\subsection{Political party identification and stock market participation}

Existing evidence suggests that political preferences are associated with socioeconomic outcomes and more specifically with the portfolio decisions of investors. In a Finnish study, Kaustia and Torstila (2011) find that both individual voters and members of parliament who have a more left-wing outlook are less likely to participate in the stock market. They attribute this to "value expressive" considerations, namely the idea that personal values dictate decisions. Negative perceptions about the stock market, for example that it is a source of greed or speculation or unethical behaviour, may make individuals less inclined to participate, even in the face of evidence that the stock market outperforms alternative asset classes. This feeling of discomfort when simultaneously holding two or more 
conflicting ideas is known as "cognitive dissonance" (Festinger, 1957). This can be regarded as an additional participation cost and some investors may stay out of the stock market to avoid it. Along similar lines, Hong and Kostovetsky (2012) find that political preferences influence the asset allocation decisions of relatively sophisticated US investors: mutual and hedge fund managers who donate to the Democratic Party underweight socially contentious firms, with the reverse pattern evident for fund managers who donate to the Republican Party.

The expressions of political preferences in elections are determined, at least in part, on the ideological positions of political parties (Sanders, 1999). However, this factor has declined in importance with voters placing more weight on the competitiveness of party policies (Clarke et al., 2004). In the UK, evidence suggest that elections are generally determined by two competing sets of influences: 'consumer voting' based on evaluations of political party competence (Clarke et al., 2004; Green and Hobolt, 2008) and political party identification based upon ideological differences, albeit against a background of ideological convergence (Sanders, 2003). Despite the evidence that consumer voting has increased in the UK, Sanders (2003) argues that party identification is still an important consideration. We might therefore expect some potential investors with left-wing political leanings to stay out of the stock market to avoid the participation cost associated with cognitive dissonance.

Irrespective of political preferences, interest in politics may have a positive impact on stock market participation. Using US and European data, Bonaparte and Kumar (2013) find that politically active individuals, defined as those who say that they vote more often, are more likely to participate in the stock market. Bonaparte and Kumar attribute this to such individuals following political news more actively, 
thereby increasing their chance of being exposed to financial news. This lowers their information gathering costs and thus increases stock market participation. We investigate the relationship between political party identification and stock market participation, and analyse how the relationship varies by political party allegiance and the impact of shifts in this allegiance over time. Based on the idea that information-gathering costs are lower for those who identify with a political party, the hypothesis that we test is:

Hypothesis 5: Individuals who identify with political parties are more likely to participate in the stock market.

\section{Data}

\subsection{Description and construction of the variables}

This study uses data from the BHPS that provides annual individual and household information about social and economic variables. The original sample of the BHPS was approximately 5,500 households consisting of 14,000 individuals from across the UK, subsequently increased by additional samples from Scotland and Northern Ireland $^{3}$. The BHPS has three features that are relevant to this study. First, and most important, it provides data on both social engagement measures and stock market participation at the individual level. Second, it facilitates analysis of the impact of generational and age effects. This is important because levels of social engagement - the number of social groups, participation during elections, the frequency of reading newspapers, and social trust - have been found to be non-linear functions of age; they increase towards middle age, remain constant during middle age, and

\footnotetext{
${ }^{3}$ The BHPS consists of 18 waves to 2008. Since 2010 (Wave 19), the BHPS has been replaced by, and incorporated into, the United Kingdom Household Longitudinal Study (UKHLS).
} 
decline as individuals advance in age (Putnam, 1995). Further, it is arguable that social engagement is attributable to generational effects, so that belonging to a specific cohort is associated with increased/decreased levels of social engagement (Putnam, 1995). Most studies are restricted to specific cohorts (e.g. Hong et al., 2004; Bogan, 2008), limiting the extent to which inferences can be made about the general population. Therefore, we use BHPS cohorts and ages ranging from 1900 to 1979 and 19 to 98 respectively. Third, by its structure the BHPS minimises the problem of sample attrition - respondents who participate in a few waves or completely drop out of the sample - by a process of re-weighting the cases who gave full interviews at all waves (for a detailed explanation, see Taylor (2010)).

Our use of the BHPS is limited to the years 1995, 2000 and 2005 because, to date, these are the only years in which investment questions were asked. For variables not observed during these three waves, we impute responses using the observations in either succeeding or preceding waves ${ }^{4}$ and thus we assume that these imputed social engagement measures and controls do not vary in a manner that will materially affect our results.

Table I shows how each variable is constructed. In the survey, individuals are first asked whether they have money in investments and, if they answer 'yes', they select the financial instruments in which the money is invested - national savings certificates, premium bonds, unit trusts, personal equity plans, shares (UK or foreign), national savings / building society, insurance bonds and other investments.

\footnotetext{
${ }^{4}$ Access to the Internet from home - wave 6 and 10 onwards; social interaction - wave 7 onwards; social group membership - skipped annually after wave 2 ; religion - wave 1, 7, 9, 11, 14 and 18; trust - wave 8, 10, 13, 15 and 17; and life events - waves 2, 3, 4, 5, 9, 11 and 14.
} 
We define the dependent variable, stock market participation 1 (SMP1), as a dummy variable taking the value one if the individual holds either unit trusts or shares. This definition provides the minimum degree of stock market participation because individuals may also invest indirectly through retirement plans and other financial instruments that include stocks. An alternative dependent variable (SMP2) includes investments in PEPs, Tessas and ISAs and, along with two further alternatives, investment in fixed interest assets and the number of investment products, described in Table I, are used for robustness checks, which confirm our key results.

\section{Insert Table I Somewhere Here}

We generate five social engagement variables. Of these, two represent strong and weak ties. The proxy for strong ties is the frequency of talking to neighbours and takes the value one if a respondent talks to neighbours "everyday", "once in a week" or "once in a month" (92.8\%) and the value zero if "rarely" or "never" $(7.2 \%){ }^{5}$ The proxy for weak ties is based on social group activity. We define the variable active in social groups as a dummy variable that takes the value one if a member is active and the value zero otherwise. We also use four dummy variables derived from the number of organisations ${ }^{6}$ respondents are members of as an alternative proxy for weak ties. To control for neighbourhood effects, which may

\footnotetext{
${ }^{5}$ Alternative definitions of the talking to neighbours variable are also generated using different $(0,1)$ combinations of the five categories defined in Table I. Comparable results obtained for these other definitions are available from the authors.

${ }^{6}$ The organisations listed include political party, trade union, environmental group, parents association, tenants or residents group, religious group, voluntary service group, other community group, social group, sports club, women's institute, women's group, other organisation, professional organisation, pensioners organisation and scout/guides organisation.
} 
contaminate these variables, we include two dummy variables. The first is the variable good neighbourhood, which takes the value one if a respondent thinks that her/his neighbourhood is a "good" place to live in and the value zero if the response is "moderate" or "bad". The second is the variable concentrated housing, which takes the value one if the type of accommodation is "detached", "semi-detached", or "terraced" and the value zero if it is a "converted flat", "purpose built flat" or any other type of housing.

Trust is a binary variable taking a value of one for positive responses to the question: "generally speaking, would you say that most people can be trusted or that you can't be too careful in dealing with people?" Religiosity is measured by the dummy variable religion makes a difference. This takes a value one if respondents answer: a little difference, some difference or a great difference to the question: "how much difference would you say religious beliefs make to your life?" It takes the value zero if the answer is no difference.

Political party identification is derived using answers to four questions about interest in politics. First, all respondents are asked whether they support a particular political party to which the response is either 'yes' or 'no'. Second, If the response is 'no', the respondent is asked whether she/he is 'closer to one political party than another'. Third, respondents who do not support or feel closer to one political party than another are asked to identify the political party they would vote for tomorrow. Finally, respondents who support a particular political party or feel closer to one political party than another are asked to identify the particular political party. By combining responses to these questions, a respondent is classified as having no political inclination if she/he does not support any political party; is not closer to one political party than another; or does not identify a political party he/she would vote for 
tomorrow. Otherwise, respondents are categorised as belonging to the Conservative Party, the Labour Party, the Liberal Democratic Party, or other parties ${ }^{7}$ based on the party they would vote for tomorrow or that they identified in the last question. The variable therefore captures both political ideology and consumer voting. We generate five dummy variables for each category. Finally, we use a comprehensive set of socio-economic and demographic control variables, described in Table I.

Our proxy for the control variable Financial Capability uses the responses to seven BHPS questions about financial management, as reported in Table I. It is similar to the approach of Hilgert et al. (2003) and Atkinson et al. (2007) and follows the method used by Taylor et al. (2009) in their construction of a financial incapability index. However, we invert our index so that positive values represent financial capability $^{8}$.

\subsection{Descriptive Statistics}

Table II presents weighted summary statistics for the whole sample. The most popular investment vehicles among individuals in our sample are savings accounts (63\%), premium bonds (22\%) and ISAs (20\%), and direct shareholding (18\%). SMP1 and SMP2 respectively represent $21 \%$ and $35 \%$ of money invested, while the proportion of those who invest in less risky assets is $28 \%$. The figures for the type of investment do not add up to $100 \%$ since individuals may hold more than one

\footnotetext{
${ }^{7}$ The "other parties" category includes regional parties such as the Scottish National party, Plaid Cymru and other smaller parties.

${ }^{8}$ The response categories to the questions were recoded to remove missing values and standardized (to have a mean zero and a variance of one). The constructed index has a 0.7036 Cronbach's alpha with a 0.2532 average inter-item correlation. These values provide a satisfactory level of internal consistency (for a detailed discussion see Taylor et al., 2009). The higher the index value the higher the financial capability.
} 
instrument. On average, $92.8 \%$ of the respondents acknowledge that they talk to their neighbours. The other social engagement measures have lower averages but their standard deviations indicate a higher variation relative to the mean than the talking to neighbours variable. The financial capability index takes negative and positive values, with increasingly negative values representing declining financial capability and increasingly positive values representing improving financial capability. The mean of zero implies that on average respondents are financially capable.

\section{Insert Table II here}

The measures of social engagement - talking to neighbours, active in social groups, trusts most people, and religion makes a difference - have moderate correlations ranging from -0.031 to $0.115^{9}$. Surprisingly, the variable religion makes a difference is negatively correlated with other proxies for social engagement suggesting that religious people are less likely to talk to their neighbours frequently, to get involved in social groups, and to trust most people. Having no party affiliation and being affiliated with other smaller parties are negatively correlated with talking to neighbours, active in social groups and trusts most people, whereas affiliation to the Liberal Democratic Party and the Conservative Party are both positively correlated with these variables. Generally, the correlations are low between most of the control variables and the variables of interest. Therefore, we expect each variable to provide independent information in relation to stock market participation.

\footnotetext{
${ }^{9}$ Correlation coefficients for all of the variables are available from the authors.
} 


\subsection{Econometric model}

From the summary statistics reported in Table II, we observe variations in the key independent variables. Further, respondents do not substantially change their stock market participation status from one period to the other ${ }^{10}$ and, across all the independent variables, the between variations are about double the within variations. This implies that if we were to use a fixed effects model, individuals who do not change participation status over the panel period will not contribute to the estimation, making the identification harder. This suggests that a pooled probit model is more appropriate for our data. We cluster standard errors at the individual level. We therefore estimate the general static binary response model given by:

$$
\begin{array}{r}
y_{i t}^{*}=\delta_{0}+X_{i t} \beta+z_{i} \alpha+u_{i}+\varepsilon_{i t}, \\
y_{i t}=1 \text { if } y_{i t}^{*}>0 \text {, and } y_{i t}=0 \text { otherwise. }
\end{array}
$$

where $y_{i t}^{*}$ is a latent variable, $y_{i t}$ is the dummy for observed stock market participation, $X_{i t}$ are the time varying explanatory variables, $z_{i}$ are the time invariant control variables, $u_{i}$ is an error term, and $\varepsilon_{i t}$ a transitory error term.

First, we investigate whether strong and weak ties are distinct measures of social interaction. As discussed in section 2, our proposition is that weak ties provide sources of new information. This has three implications: (1) non-participants are more likely to participate in the stock market upon joining a social group; (2) the more social groups an individual is involved with, the higher the effects on

\footnotetext{
${ }^{10}$ For example, among respondents who were out of the stock market in one period, $88 \%$ remained out of the market in the next period compared to $57 \%$ for those who participated in the market.
} 
participation; and (3) most important, in an equation that includes both channels, measures of strong ties should have insignificant effects. We estimate the following equations:

$$
\begin{gathered}
S M P_{i t}=S I_{i t} \beta_{j}+C V_{i t} \alpha+u_{i}+\varepsilon_{i t}, \\
S M P_{i t}=T T N_{i t} \beta_{1}+A S G_{i t} \beta_{2}+C V_{i t} \alpha+u_{i}+\varepsilon_{i t} .
\end{gathered}
$$

Where $S M P_{i t}$ is a dummy for stock market participation for individual $i$ in year $t$. The social interaction $(S I)$ variable of interest in eq. (2) is either talking to neighbours (TTN) or active in social group (ASG) and both variables are combined in eq. (3). The control variables (CV) are housing tenure, financial capability index, has no debt, received windfall income, computer user, cohorts, good health, male, age, married, has child(ren), highest qualification, economic activity, government office region and income quintiles. The error term $u_{i}$ represents unobserved individual effects.

Second, we investigate whether each of the social engagement measures have independent effects on stock market participation. We should expect to see significant effects if each social engagement measure is analysed in isolation, as in:

$$
S M P_{i t}=S E M_{i t} \beta_{j 1}+C V_{i t} \alpha_{j 4}+u_{i}+\varepsilon_{i t}
$$

The social engagement measures (SEM) include the social interaction variables in eq. (3), trusts most people (TMP), and religion makes a difference $(R M D)$. However, we contend that the measures may capture the same underlying information or affect the control variables, so we expect to see increased, diminished 
or insignificant effects in the equation that brings social engagement measures together, as in:

$$
S M P_{i t}=T T N_{i t} \beta_{1}+A S G_{i t} \beta_{2}+T M P_{i t} \beta_{3}+R M D_{i t} \beta_{4}+C V_{i t} \alpha+u_{i}+\varepsilon_{i t} .
$$

The variables are estimated in isolation in eq. (4) and are combined in eq. (5).

Third, we examine the role of political party identification. Two implications emerge from the literature: (1) if party identification matters, those who identify with right-wing parties are more likely to participate in the stock market; (2) otherwise, if policies are very similar and evaluation of political party competence is more important, party identification should have less influence on participation. The model is represented by:

$$
S M P_{i t}=P I_{i t} \delta_{j}+C V_{i t} \alpha_{j}+u_{i}+\varepsilon_{i t}
$$

Where the dependent and control variables are as described in equations $1-4$ and the additional variable of interest is party identification $(P l)$.

Finally, we pool all of these factors to estimate the determinants of stock market participation. Again, we contend that there may be correlations between social engagement measures and party identification, or with other variables such as housing (El-Attar and Poschke, 2011). The model is represented by:

$$
S M P_{i t}=S C M_{i t} \beta_{j}+P I_{i t} \delta_{j}+C V_{i t} \alpha_{j}+u_{i}+\varepsilon_{i t}
$$

The dependent variable and explanatory variables are as defined in equations 1 - 6 .

\section{Empirical results}

Each of our results tables reports the effects of our independent variables on stock market participation separately and jointly. The results of the separate estimations broadly follow those for prior studies discussed in the literature review. In contrast, 
when all of the variables are brought together in a general specification the results provide the main contribution of our study by showing which independent variable associations remain significant. When the social engagement variables are combined together sequentially the results suggest that more socially engaged respondents are more likely to participate in the stock market.

\subsection{The role of social interaction, trust and religion}

Table III presents the marginal effects from unbalanced pooled probit estimates using seven specifications. Panel A shows the marginal effects at means (MEMs) while Panels $B$ and $C$ present the marginal effects at representative values (MERs). We calculate the joint effects of our social engagement measures in Panel D. In all the specifications we control for good neighbourhood, concentrated housing, housing tenure, received windfall income, has no debt, financial capability, computer use, good health, male, age, age square, cohort, married, has child(ren), highest qualification, economic activity, government office region and income, as defined in Table I.

\section{Insert Table III Somewhere here}

Table III, Panel A, reports MEMs for each of the social engagement measures, first separately and then together. In column 1 , the variable of interest is talking to neighbours as used by Hong et al. (2004). In the second specification, column 2, we test the separate influence of the variable active in social groups as used by Georgarakos and Pasini (2011). In contrast to the findings of Hong et al. (2004) and hypothesis 1, when MEMs are estimated in isolation we do not find a 
correlation between talking to neighbours and stock market participation. ${ }^{11}$ Consistent with the prior literature and hypothesis 2, we find that when MEMs are estimated in isolation, individuals who are active in social groups appear more likely to participate in the stock market. Similarly, column 3 indicates that trusting individuals are more likely to participate in the stock market (in line with hypothesis 3), while those who say that religion makes a difference in their lives, column 4 , are less likely to participate (contrary to hypothesis 4). Control variables have the expected signs, are significant at the $1 \%$ level, and are stable across the four specifications.

In column (5) we use a single regression that includes both talking to neighbours and active in social groups. The effects remain insignificant for talking to neighbours but significant for active in social groups. When we combine all the social engagement measures in one regression, column (6), the variables active in social groups, trusts most people, and religion makes a difference have independent positive effects on stock market participation, but religion has a negative effect and talking to neighbours remains insignificant. This result suggests that the marginal utility of information provided by strong ties remains insignificant in the presence of other social engagement variables.

In column (7), we replace the binary social group dummy with a categorical variable representing the number of social groups with which an individual is involved. The idea is that involvement in many social groups exposes an individual to

\footnotetext{
${ }^{11}$ When we run this regression and exclude the variables good neighbourhood, concentrated housing, housing tenure, received windfall income, computer use, has no debt, financial capability and cohort, the variable talking to neighbours becomes significant at the $5 \%$ level.
} 
a variety of sources that enhance the chances of encountering financial market information. The results indicate that individuals who are involved in three or more social groups are more likely to participate in the stock market than those involved in only one group.

Given that MEMs do not represent actual individual characteristics, these interpretations may be incorrect (Ai and Norton, 2003; Williams, 2012; Bartus, 2005). Therefore, we also use MERs to interpret our results in Panels $B, C$, and D. Panel B shows MERs calculated using base characteristics for all variables, apart from the social engagement variable of interest, in each specification. Base characteristics represent an individual who: does not talk to neighbours; is not active in social groups; can't be too careful - does not trust others; believes that religion makes little or no difference in life; and has no political identification; rents current accommodation; has not received windfall income; has debt; has a financial capability index value equal to the mean; is not a computer user; has bad health; is a female; is not married; does not have children; has no educational qualification; is unemployed; lives in the North East of England; and is categorised in the 1st income quintile. For example, in specification (1) we examine the marginal effect of talking to neighbours holding both the other social engagement measures and the control variables at their base levels. The results in panel B are consistent with those of panel $A$ in that the effects for active in social groups, trusts most people and religion makes a difference are significant at the $1 \%$ level in specifications (2) to (4) respectively and at varying levels of significance when estimated in the combinations shown by specifications (5) through (7). Conversely, unlike base characteristics, varied characteristics take the maximum values of each variable, apart from region, which becomes East of England. Therefore, in Panel C, we consider an individual 
with varied characteristics and we replicate the marginal effects calculated in Panel $B$ and find consistent results. Comparing the MERs in Panels B and C, we clearly see that social engagement can distinguish stock market participants from nonparticipants and that the measures have independent effects on stock market participation, thus confirming the results of our analysis using MEMS.

In Panel D we cumulatively add the effects of the social engagement measures in specifications (5), (6) and (7). The marginal effects reported show the increasing/(decreasing) joint marginal effect on stock market participation as each social engagement measure is included in the calculation, keeping the remaining measures at their base levels. The reference person for our calculation of joint marginal effects exhibits the varied characteristics previously described for Panel C above and, in addition, cumulatively adds the four social engagement measures, beginning with talking to neighbours. For example, in specification (5) row (1), we first evaluate the effect of talking to neighbours and then evaluate the marginal effects of both talking to neighbours and active in social groups in row (2), holding the other social engagement measures at their base levels and using the reference person characteristics. Consistent with the previous results, talking to neighbours has an insignificant effect in all the specifications. When we consider a reference person that talks to neighbours and is active in social groups, row (2), the marginal effects on stock market participation are $3.23 \%$ and $2.67 \%$ in specifications (5) and (6) respectively. In specification (6), if he or she also trusts most people, the effects increase to $5.1 \%$, but reduce to $3.9 \%$ if he or she also believes that religion makes a difference. Similarly, in specification (7), we see that the incremental marginal effect of talking to neighbours and involvement in three or more social groups is $8.2 \%$; and that the incremental marginal effect of talking to neighbours, involvement in three or 
more social groups and trusting most people, is $11.0 \%$, but falls back to $9.8 \%$ if religion makes a difference. The results in Panel D suggest that intensity of social engagement generally increases the likelihood of stock market participation.

\subsection{The role of political party identification}

In this section, we extend the analysis to include political party identification and report both MEMs (Panel A) and MERs (Panels B, C, and D) in Table IV. In specification (1) we regress stock market participation against political party identification together with the standard controls and we include the other social engagement measures in specification (2) and the categorical variable number of social groups in specification (3).

Panel A of Table IV, column (1) presents the estimates for the association between stock market participation and political party identification in isolation. The results show that individuals who identify themselves with a mainstream political party are more likely to participate in the stock market as compared to those who do not have a political affiliation, consistent with hypothesis 5 . However, some party affiliations have a greater effect. For example, the effect of identification with the Conservative Party is about one and half times larger than that of Liberal Democratic Party identification and six times that of Labour Party identification.

\section{Insert Table IV Somewhere here}

In column (2), we combine other social engagement measures and party identification in a single equation. The results show that social group involvement, trust, religion, and identification with the Liberal Democratic Party and the Conservative Party have independent effects on stock market participation. The variables talking to neighbours and identification with the Labour Party are 
insignificant. Comparing these results with those in Table III, column (6), the effects are comparable for the variables active in social groups and religion makes a difference, suggesting a minimal correlation with party identification. When we use the number of social groups, column (3), in place of the social groups dummy variable, the effects of trusts most people, identification with the Liberal Democratic party and identification with the Conservative Party remain significant. The variable religion makes a difference now becomes insignificant. The results for the variable number of social groups remains virtually unchanged from the results reported in Table III.

In Panels B and C of Table IV, we calculate MERs using base and varied characteristics respectively. In Panel $B$, we see that the marginal effects are consistent and significant for party identification, social group involvement and trust (at levels varying between $1 \%$ and $5 \%$ ). Further, as seen in the previous section, the magnitudes are small, in contrast to the results reported in Panel $\mathrm{C}$ where, across all specifications, the magnitudes are higher, and significant at the $1 \%$ level for identification with the Liberal Democratic Party and the Conservative Party, involvement in social groups and trust.

Panel D presents the joint marginal effects of social engagement, which are evaluated using the reference person characteristics and by cumulatively adding the effects of social engagement variables. The results show that identification with the Conservative Party has an $8 \%$ effect on stock market participation when other social engagement variables are held at their base levels. When we consider that the reference person also talks to neighbours, is active in social groups, trusts most people and believes that religion makes a difference, the joint effects are $13 \%$ for specification (2) and $20.6 \%$ for specification (3). In both specifications the variable 
religion makes a difference has a negligible impact. The results are consistent with those reported in Table III, Panel D, and confirm that the variables active in social groups, trusts most people, and political party identification jointly increase the likelihood of stock market participation. Furthermore, considering that the mean rate of stock market participation is only $21 \%$, the reported joint effects of social engagements are influential. Overall, the results suggest that socially engaged respondents are more likely to participate in the stock market with statistically and economically significant effects.

\subsection{The conditional marginal effects of social interaction, trust, religion and political party identification}

We now consider the conditional marginal effects of all of our social engagement measures. However, for limited dependent variable models in which marginal effects are calculated at means for an interaction term, the sign, significance and magnitude may not reflect the true relationship between variables (Ai and Norton 2003). In order to interpret the interaction term correctly, we calculate conditional marginal effects at representative values as suggested by Ai and Norton (2003). The marginal effects of the interaction term are then presented graphically, following Greene (2012).

Figure 1 shows the marginal effects by political party identity and across age when we interact the variables trusts most people, active in social groups, religion makes a difference and political party identification. The effects and the levels of significance of these variables vary across party identification. For small parties, social group involvement is significant and positive; for the Labour party and the Conservative party, both social group involvement and trust are significant and positive; and for the Liberal Democratic Party, none of the variables are significant. 
It is interesting to note that the effects of all the variables are insignificant among respondents who have no party identity, which suggests that these individuals are also disengaged from other social mechanisms and are thus less likely to invest in the stock market. This is consistent with the information gathering costs hypothesis of Bonaparte and Kumar (2013). For those who identify with the Labour party, its left-of-centre political ideology, which might in theory restrain stock market investment, is compensated for by trust and involvement in social groups. These same variables increase stock market participation for those who identify with the Conservative party. Religion has no impact on stock market participation for those who identify with both the Labour party and the right-of-centre Conservative party.

\subsection{The effect of a shift in political party identification}

In this section, we investigate transitions in political party identification and their impact on stock market participation. Intuitively, if political parties' ideological and policy positions converge, individuals should become indifferent in their party choices on these grounds and instead shift political affiliation in line with perceived party competence, principally in economic management. Thus, transitions from one party to the other may be correlated with stock market participation. Our findings partially support this hypothesis.

As discussed in section 2, if 'consumer voters' are driven by the desire to protect their investments, we would expect them to penalize their own parties by voting for another party that they believe is more competent in economic management. Thus, we should expect to see a positive relationship between change in political party identification and stock market participation if economic 
management is a signal of pro-market policies. Alternatively, where 'consumer voters' change party preferences in reaction to policy positions taken by a political party, not necessarily because of their views about competence in economic management, then we should expect a negative association. To explore this, we examine shifts in political party identification. From our data, the transitional probabilities for political party identification reveal substantial transitions between political parties during the three waves. In order to capture these shifts, we generate a dummy variable (political party shift) that takes the value one for those who change parties during the three waves and zero otherwise. We find that $35 \%$ of the respondents changed their preferred political party during the three waves.

We first replace political party identification with the indicator of political party shift in the complete model. The results in Table $\mathrm{V}$, column (1) show that the variable has an insignificant effect on stock market participation. In column (2), we run a regression that includes the two variables to examine their independent effects on stock market participation. The negative political party shift coefficient becomes significant, but only at the $10 \%$ level, while the effects of political party identification retain the same levels of significance as seen before.

\section{Insert Table V Somewhere here}

In column (3) we interact the two variables using the specifications in our complete model. The effect of political party shift is still significant at the $10 \%$ level. The interaction terms are positive and significant for the Conservative Party and the Liberal Democratic Party and insignificant for Small Parties and the Labour Party. When presented graphically, in line with Greene (2012), the true marginal effects of the interaction between political party shift and political identity have different signs 
to the MEMs reported in Table $\mathrm{V}$. The marginal effects of political party shift differ across both political party identification and age. Figure 2 presents MERs using base characteristics while Figure 3 is derived using varied characteristics. Political party shift has a negative and significant effect on stock market participation among those who identify with the Conservative Party. In contrast, the marginal effect of political party shift is not significant for those who identify with the Liberal Democratic Party, the Labour Party and for respondents with no party affiliations. In summary, those who identify with the Conservative or the Liberal Democratic Party and have not shifted allegiance from another party (Tables IV and V) are more likely to participate in the stock market than an individual identifying with another party or no party. However, those who have recently shifted allegiance to the Conservative Party are less likely to participate in the stock market than those who have a longer-term

allegiance to the Conservatives. As hypothesised in section 2.3, this suggests that both political party identification and consumer voting behaviour are associated with stock market participation.

\section{Robustness checks}

We consider alternative specifications and definitions of stock market participation to examine whether our results are consistent. Table VI presents marginal effects using the following four dependent variables: our standard definition of stock market participation (SMP1) with lagged SMP1 as an additional independent variable (column 1); the alternative stock market participation definition, SMP2 (column 2); 
fixed income assets (column 3); and number of investment products (column 4) using the specifications in Table IV, column $2^{12}$.

\subsection{Lagged value of Stock Market Participation}

In section 3.3 we note that transitions in (out) of the stock market are minimal, while most respondents tend to remain in the same state within the panel. This suggests that SMP1 in 2005 is likely to be influenced by participation in 2000 or 1995 . To isolate the effects of state dependence we include a one period lag of the principal dependent variable as a control in Table VI, column 1. The lagged dependent variable enters with a value of $35 \%$ and is significant at the $1 \%$ level. Moreover, this specification appears to capture a lot of variation in the data as indicated by the pseudo $r^{2}$, which increases to $27 \%$ from the $16 \%$ value reported in Table IV (Column 2). Nevertheless, the social engagement variables - active in social group, trusts most people, and identification with the Liberal Democratic Party and the Conservative Party - remain significant at the $1 \%$ level. The variable religion makes a difference becomes insignificant.

\section{Insert Table VI Somewhere Here}

\subsection{Alternative dependent variables}

Saving money in personal equity plans, Individual Savings Accounts, and other forms of equity investments (SMP2) provides opportunities for both portfolio diversification and efficient tax management. Plausibly, individuals who are more informed about financial market operations and are aware of changes in government policy are more likely to take advantage of the opportunities such knowledge provides. Based on our propositions regarding social interaction, trust, and party

\footnotetext{
${ }^{12}$ In columns (1) - (3) we use pooled probit regressions but in column (4) we use a Poisson regression because (NIP) is not a binary variable.
} 
identification, we should observe increased effects on our variables of interest when we use this broader definition of stock market participation as the dependent variable. The marginal effects presented in Table $\mathrm{VI}$, column 2, show that the variables active in social groups, trust most people, and party identification increase by more than $50 \%$. The variable religion makes a difference becomes significant at the $5 \%$ level. The effects of identification with smaller parties and the Labour Party are still lower than identification with the Liberal Democratic Party and the Conservative Party, but become significant at the $10 \%$ and $5 \%$ levels respectively ${ }^{13}$.

Fixed Interest Assets (FIA) are both relatively safer and less information intensive than stocks, which make them attractive to less sophisticated investors as well as providing diversification opportunities to stock market participants. Characteristically, non-stock market participants in our model are less social, less trusting, and do not identify themselves with any political party and are therefore more likely to hold FIA. Thus, we should expect these factors to have a lesser, or negligible, effect on the decision to hold FIA. Table VI, column 3, presents marginal effects where the dependent variable is an indicator of ownership of Fixed Interest Assets (FIA) and the explanatory variables are as described in our final model. When compared to the results in column 2 , the effect of trust declines in significance and the negative effect of religious beliefs increases in significance. For those who identify with other smaller parties the effect becomes insignificant, while for those who identify with the Liberal Democratic party the positive effect declines in significance from $1 \%$ to $5 \%$ and for the Labour Party the previously positive effect remains significant at the $1 \%$ level but the sign reverses. However, the effects of

\footnotetext{
${ }^{13}$ A similar pattern is observed for most of the control variables though the effects of holding other higher qualification, a first degree or above qualifications, and financial capability almost doubles.
} 
some of the control variables change substantially. The variable has no debt becomes insignificant while the variable male becomes negative and is significant at the $1 \%$ level. The effect of the variable received windfall income is more than double that reported in Table IV and 50\% more than that in Table VI, Column (2).

Finally, we use the Number of Investment Products (NIP) owned by respondents as an alternative dependent variable. Here, our intuition is that individuals who are informed about financial market operations, investment products and government policy changes are more likely to hold a higher number of investment products. In Table $\mathrm{VI}$, column 4, we report marginal effects from poisson estimates using the specifications in our final model. The findings confirm our previous results: individuals who are active in social groups, trust most people, and identify themselves with the Liberal Democratic Party and the Conservative Party are more likely to hold a higher number of investment products. Overall, our robustness tests confirm our conclusions derived from section 4 .

\section{Conclusion}

Most previous studies report a positive association between stock market participation and social engagement measures when analysing each of these variables separately. While some recent studies consider the presence of possible correlations between these factors, to the best of our knowledge none carry out a holistic analysis. Our rich dataset enables us to address this gap.

Using three waves in the BHPS we tackle four unresolved issues. First,

recognising that social engagement can give rise to two distinct channels of social interaction, we disaggregate channels of social interaction using the categories talking to neighbours (strong ties) and active in social groups (weak ties). Second, 
we test the independent effects of all of our social engagement measures in the same model. Third, we use an integrated measure of political party identification to examine the role of political identity and shifts in political party preferences. We disaggregate the influence of social engagement, political ideology and shifts in political party preferences within the same model using interaction terms. Finally, we calculate marginal effects at representative values for the independent and joint influences of social engagement.

We conclude that weak ties are more effective and productive channels of social interaction than strong ties. Our measure of strong ties, frequency of talking to neighbours, seems only to capture the information in other social engagement and control variables. In addition, we show that, when modelled in isolation from other variables, individuals who have more weak ties, i.e. are involved in more social groups, are more trusting, and are members of either the Conservative or the Liberal Democratic parties, are more likely to participate in the stock market. Contrary to prior literature, religiosity has a negative effect on stock market participation. When estimated together in one model, the effects of strong ties remain insignificant, while the effects of weak ties, trust, religion and alignment to the Conservative Party or the Liberal Democratic Party have independent effects on stock market participation.

When we interact our social engagement measures, for those who do not identify with a political party or who identify with the Liberal Democratic Party, social group involvement and trust have no impact on stock market participation. In contrast, these two variables influence stock market participation among those who identify with either the Labour Party or the Conservative Party, suggesting that their influence is independent of political ideology. Social group involvement influences stock market participation among those who identify with small parties. When we 
consider shift in political affiliation, we find that those who shift to the Conservative Party are less likely to participate in the stock market than those who consistently identify with the Conservatives. The net cumulative effect of our social engagement measures is that the probability of stock market participation increases by $21 \%$.

Our study has potential policy implications. The findings suggest that policy makers and financial institutions wishing to enhance stock market participation should focus their attention on the provision of information to those who are least socially engaged. Of the low engagement groups, particular emphasis should be placed upon those who have the fewest weak ties because they are likely to have the least access to productive information. Given our finding that individuals who are more trusting are more likely to participate in the stock market, policies that enhance trust in stock market investments and the investment process generally are likely to enhance participation. This will also lower the participation cost associated with the cognitive dissonance experienced by those whose political or religious leanings are inclined against stock market participation. 


\section{References}

Ai, C. and Norton, E.C. (2003) Interaction terms in logit and probit models, Economics Letters 80, 123-129.

Atkinson, A., McKay, S., Collard, S., and Kempson, E. (2007) Levels of financial capability in the UK, Public Money \& Management 27, 29-36.

Banerjee, A.V. (1992) A simple model of herd behavior, The Quarterly Journal of Economics 107, 797-817.

Bartus, T. (2005) Estimation of marginal effects using margeff, Stata Journal 5, 309329.

Becker, G.S. (1991) A note on restaurant pricing and other examples of social influences on price, The Journal of Political Economy 99, 1109-1116.

Bjørnskov, C. (2006) The multiple facets of social capital, European Journal of Political Economy 22, 22-40.

Bogan, V. (2008) Stock market participation and the Internet, Journal of Financial and Quantitative Analysis 43, 191-211.

Bonaparte, Y. and Kumar, A. (2013) Political activism, information costs, and stock market participation, Journal of Financial Economics 107, 760-786.

Brown, J.R., Ivković, Z., Smith, P.A., and Weisbenner, S. (2008) Neighbors matter: Causal community effects and stock market participation, Journal of Finance 63, $1509-1531$. 
Campbell, J.Y., Jackson, H.E., Madrian, B.C., and Tufano, P. (2011) Consumer financial protection, Journal of Economic Perspectives 25, 91-114.

Christelis, D., Jappelli, T., and Padula, M. (2010) Cognitive abilities and portfolio choice, European Economic Review 54, 18-38.

Clarke, H., Sander, D., Stewart, M., and Whiteley, P. (2004) Political Choice in Britain, Oxford University Press, Oxford.

El-Attar, M. and Poschke, M. (2011) Trust and the choice between housing and financial assets: Evidence from Spanish households, Review of Finance 15, 727 756.

Festinger, L. (1957) A Theory of Cognitive Dissonance. Stanford University Press, Stanford, California.

Georgarakos, D. and Pasini, G. (2011) Trust, sociability, and stock market participation, Review of Finance 15, 693-725.

Granovetter, M.S. (1973) The strength of weak ties, American Journal of Sociology 78, 1360-1380.

Granovetter, M.S. (1983) The strength of weak ties: A network theory revisited, Sociological Theory 1, 201-233.

Granovetter, M.S. (2005) The impact of social structure on economic outcomes, The Journal of Economic Perspectives 19, 33-50.

Green, J. and Hobolt, S.B. (2008) Owning the issue agenda: Party strategies and vote choices in British elections, Electoral Studies 27, 460-476. 
Greene, W.H. (2012) Econometric Analysis. 7th edition. Pearson Higher Education, Harlow.

Gruber, J. (2005), Religious Market Structure, Religious Participation, and Outcomes: Is Religion Good for You? National Bureau of Economic Research, Cambridge, Massachusetts, Working Paper No. 11377.

Guiso, L., Haliassos, M. and Jappelli, T. (2002) Stockholding: a European Comparison, in L. Guiso, M. Haliassos and T. Jappelli (eds.) Stockholding in Europe, Palgrave Macmillan, Basingstoke.

Guiso, L., and Jappelli. T. (2005). Awareness and Stock Market Participation. Review of Finance 9:537-67.

Guiso, L., Sapienza, P., and Zingales, L. (2003). People"s opium? Religion and economic attitudes, Journal of Monetary Economics 50, 225-282.

Guiso, L., Sapienza, P., and Zingales, L. (2004) The role of social capital in financial development, The American Economic Review 94, 526-556.

Guiso, L., Sapienza, P., and Zingales, L. (2008) Trusting the stock market, Journal of Finance 63, 2557-2600.

Halek, M. and Eisenhauer, J.G. (2001) Demography of risk aversion, Journal of Risk and Insurance 68, 1-24.

Haliassos, C.C. and Bertaut, M. (1995) Why do so few hold stocks?, Economic Journal 105, 1110-1129. 
Harper, R. and Kelly, M. (2003) Measuring Social Capital in the United Kingdom, Office for National Statistics, London. Available at http://www.esds.ac.uk/government/themes/socialcapital/

Hilgert, M.A., Hogarth, J.M., and Beverly, S.G. (2003) Household financial management: The connection between knowledge and behavior, Federal Reserve Bulletin 89, 309-322.

Hong, H., Kubik, J.D., and Stein, J.C. (2004) Social interaction and stock-market participation, The Journal of Finance 59, 137-163.

Hong, H. and Kostovetsky, L. (2012) Red and blue investing: Values and finance, Journal of Financial Economics 103, 1-19.

Ivković, Z. and Weisbenner, S. (2007) Information diffusion effects in individual investors' common stock purchases: Covet thy neighbors' investment choices, Review of Financial Studies 20, 1327-1357.

Kaustia, M. and Torstila, S. (2011) Stock market aversion? political preferences and stock market participation, Journal of Financial Economics 100, 98-112.

Keister, L.A. (2003) Religion and wealth: the role of religious affiliation and participation in early adult asset accumulation, Social Forces 82, 175-207.

León, A.K. and Pfeifer, C. (2013) Religious Activity, Risk Taking Preferences, and Financial Behaviour: Empirical Evidence from German Survey Data, University of Lüneburg Working Paper Series in Economics, No. 269. 
Mankiw, G. and Zeldes, S. (1991) The consumption of stockholders and nonstockholders, Journal of Financial Economics 29, 97-112.

Mehra, R. and Prescott, E.C. (1985) The Equity Premium: A Puzzle, Journal of Monetary Economics 15, 145-155.

Narayan, D. and Pritchett, L. (1997) Cents and Sociability Household Income and Social Capital in Rural Tanzania, Policy Research Working Paper 1796, The World Bank, Washington.

Nofsinger, J.R. (2005) The Psychology of Investing, Pearson/Prentice Hall, Upper Saddle River, N.J.

Noussair, C., Trautmann, S., Van de Kuilen, G. and Vellekoop, N. (2012) Risk Aversion and Religion, CentER Discussion Paper Series No. 2012-073. Available at http://papers.ssrn.com/sol3/papers.cfm?abstract id=2145276.

Putnam, R.D. (1993) Making Democracy Work: Civic Traditions in Modern Italy, Princeton University Press, Princeton, NJ.

Putnam, R.D. (1995) Tuning In, Tuning Out: The Strange Disappearance of Social Capital in America, Political Science and Politics 28, 664-683.

Putnam, R.D. (2000) Bowling Alone: The Collapse and Revival of American Community, Simon and Schuster, New York.

Renneboog, L. and Spaenjers, C. (2012) Religion, economic attitudes, and household finance, Oxford Economic Papers 64, 103-127. 
Sanders, D. (1999) The Impact of Left-Rigth Ideology, in G. Evans and P. Norris (eds.) Critical Elections: British Parties and Voters in Long-Term Perspectives, Sage Publications, London.

Sanders, D. (2003) Party identification, economic perceptions, and voting in british general elections, 1974-97, Electoral Studies 22, 239-263.

Taylor, M., Jenkins, S., and Sacker, A. (2009) Financial Capability and Wellbeing: Evidence from the BHPS, Financial Services Authority, London.

Taylor, M. F. (ed). with Brice, J., Buck, N. and Prentice-Lane, E. (2010) British Household Panel Survey User Manual Volume A: Introduction, Technical Report and Appendices. University of Essex, Colchester.

Williams, R. (2012) Using the margins command to estimate and interpret adjusted predictions and marginal effects, Stata Journal 12, 308-331.

Woolcock, M. (1998) Social capital and economic development: Toward a theoretical synthesis and policy framework, Theory and Society 27, 151-208. 


\section{Tables \& Figures}

Table I. Variable descriptions

\begin{tabular}{|c|c|c|}
\hline Variable & Description & Value \\
\hline $\begin{array}{l}\text { Dependent Variables } \\
\text { Stock market participation first } \\
\text { definition (SMP1) }\end{array}$ & $\begin{array}{l}\text { Do you currently have any money in any of the } \\
\text { investments shown? Which one? }\end{array}$ & $\begin{array}{l}\text { shares and/or unit trust }=1 \text {; other } \\
\text { or none }=0\end{array}$ \\
\hline $\begin{array}{l}\text { Stock market participation } \\
\text { second definition (SMP2) }\end{array}$ & $\begin{array}{l}\text { Do you currently have any money in any of the } \\
\text { investments shown? Which one? }\end{array}$ & $\begin{array}{l}\text { shares, unit trusts, personal equity } \\
\text { plans and TESSA/ISA }=1 \text {; other or } \\
\text { none }=0\end{array}$ \\
\hline Fixed interest assets (FIA) & $\begin{array}{l}\text { Do you currently have any money in any of the } \\
\text { investments shown? Which one? }\end{array}$ & $\begin{array}{l}\text { National savings certificate, } \\
\text { premium bonds, national savings } \\
\text { bonds, savings account, national } \\
\text { savings bank, and other } \\
\text { (investment, government or } \\
\text { company security }=1 \text {; other or } \\
\text { none }=0\end{array}$ \\
\hline $\begin{array}{l}\text { Number of investment } \\
\text { products (NIP) } \\
\text { Social engagement measures }\end{array}$ & Derived from the above categories & Number of the above held \\
\hline Talking to neighbours & How often do you talk to any of your neighbours? & $\begin{array}{l}\text { Every day, once in a week, or } \\
\text { once in month }=1 \text {; rarely or never } \\
=0\end{array}$ \\
\hline Active in social groups & $\begin{array}{l}\text { Do you join in the activities of any of these organisations } \\
\text { on a regular basis }\end{array}$ & yes $=1 ;$ no $=0$ \\
\hline Trusts most people & $\begin{array}{l}\text { Generally speaking, would say that most people can be } \\
\text { trusted, or that you can't be too careful in dealing with } \\
\text { people? }\end{array}$ & $\begin{array}{l}\text { most people can be trusted }=1 \\
\text { can't be too careful }=0\end{array}$ \\
\hline
\end{tabular}


Table I. Continued

\begin{tabular}{|c|c|c|}
\hline Variable & Description & Value \\
\hline Religion makes a difference & $\begin{array}{l}\text { How much difference would you say religious beliefs } \\
\text { make to your life? }\end{array}$ & $\begin{array}{l}\text { some or a great difference }=1 ; a \\
\text { little or no difference }=0\end{array}$ \\
\hline Political party identification & $\begin{array}{l}\text { Derived variable that combines responses to four } \\
\text { questions regarding: support of particular party, } \\
\text { closeness to one particular party than other, party which } \\
\text { would vote for tomorrow and which political party closest } \\
\text { to. }\end{array}$ & $\begin{array}{l}\text { none }=1 ; \text { Scottish National, Plaid } \\
\text { Cymru, Green Party or other party } \\
=2 ; \text { Liberal Democratic }=3 ; \\
\text { Labour Party }=4 ; \text { Conservative } \\
\text { Party }=5\end{array}$ \\
\hline \multicolumn{3}{|l|}{ Control variables } \\
\hline Good neighbourhood & Is your neighbourhood a good place to live? & Good $=1 ;$ moderate or bad $=0$ \\
\hline Concentrated housing & What type of accommodation does the household live in? & $\begin{array}{l}\text { Purpose built flats, converted flat, } \\
\text { or other concentrated housing }=1 ; \\
\text { Detached, semi-detached, or } \\
\text { terraced }=0\end{array}$ \\
\hline Housing & $\begin{array}{l}\text { Derived variable: owned outright, owned with mortgage, } \\
\text { local authority rent, housing association rented, rented } \\
\text { from employer, rented private unfurnished, rented private } \\
\text { furnished or other rented? }\end{array}$ & $\begin{array}{l}\text { all rented accommodation }=1 ; \\
\text { owned with a mortgage }=2 ; \text { owned } \\
\text { outright }=3\end{array}$ \\
\hline Received windfall income & $\begin{array}{l}\text { Since Sept. 1st } 1994 \text { have you received any payments, or } \\
\text { payment in kind? If answered yes, the amount received - } \\
\text { life insurance, pension, personal accident claim, } \\
\text { redundancy, employment bonus, inheritance/bequest, } \\
\text { pools/lottery win or something else? }\end{array}$ & yes $=1 ;$ no $=0$ \\
\hline Has no debt & $\begin{array}{l}\text { I would like to ask you now about any other financial } \\
\text { commitments you may have apart from mortgages and } \\
\text { housing related loans. Do you currently owe any money } \\
\text { on the things listed on this card? }\end{array}$ & yes =0; no = 1 \\
\hline
\end{tabular}




\begin{tabular}{|c|c|c|c|}
\hline \multirow{2}{*}{\multicolumn{2}{|c|}{$\begin{array}{l}\text { Variable } \\
\text { Financial capability index }\end{array}$}} & \multirow[t]{2}{*}{ Description } & \multirow[t]{2}{*}{ Value } \\
\hline & & & \\
\hline & $\begin{array}{l}\text { Saves from current } \\
\text { income }\end{array}$ & $\begin{array}{l}\text { Do you save any amount of your income by putting away } \\
\text { something in a bank, building society, or post office } \\
\text { account other than to meet regular bills? }\end{array}$ & yes $=1 ;$ no $=0$ \\
\hline & $\begin{array}{l}\text { Current financial } \\
\text { situation }\end{array}$ & $\begin{array}{l}\text { How well would you say you yourself are managing } \\
\text { financially these days: living comfortably; doing alright; } \\
\text { just about getting by; finding it quite difficult; and finding it } \\
\text { very difficult. }\end{array}$ & $\begin{array}{l}\text { living comfortably }=1 \text {; doing } \\
\text { alright }=2 ; \text { just about getting by }=3 \\
\text {; finding it quite difficult }=4 ; \text { or } \\
\text { finding it very difficult }=5\end{array}$ \\
\hline & $\begin{array}{l}\text { Change in financial } \\
\text { situation }\end{array}$ & $\begin{array}{l}\text { Would you say that you yourself are better off, worse off } \\
\text { or about the same financially than you were a year ago? }\end{array}$ & $\begin{array}{l}\text { better off and about the same }=1 \\
\text { worse off }=0\end{array}$ \\
\hline & $\begin{array}{l}\text { Has housing } \\
\text { problems }\end{array}$ & $\begin{array}{l}\text { Many people these days are finding it difficult to keep up } \\
\text { with their housing payments. In the last twelve months } \\
\text { would you say you have had any difficulties paying for } \\
\text { your accommodation? }\end{array}$ & no $=1 ;$ yes $=0$ \\
\hline & $\begin{array}{l}\text { Problems required } \\
\text { borrowing }\end{array}$ & $\begin{array}{l}\text { Did you have to borrow in order to meet housing } \\
\text { payments }\end{array}$ & no $=1 ;$ yes $=0$ \\
\hline & $\begin{array}{l}\text { Problems required } \\
\text { cutbacks }\end{array}$ & $\begin{array}{l}\text { Did you have to cutback in order to meet housing } \\
\text { payments }\end{array}$ & no $=1 ;$ yes $=0$ \\
\hline & $\begin{array}{l}\text { Been at least two } \\
\text { months in housing } \\
\text { arrears in last } 12 \\
\text { months }\end{array}$ & $\begin{array}{l}\text { In the last twelve months have you ever found yourself } \\
\text { more than two months behind with your rent/mortgage? }\end{array}$ & no $=1 ;$ yes $=0$ \\
\hline \multirow{2}{*}{\multicolumn{2}{|c|}{ Computer user }} & & yes $=1 ;$ no $=0$ \\
\hline & & Which item do you have? Home computer & \\
\hline \multicolumn{2}{|l|}{ Health } & $\begin{array}{l}\text { Please think back over the last } 12 \text { months about how } \\
\text { your health has been compared to people of your own } \\
\text { age, would you say that your health has on the whole } \\
\text { been ... }\end{array}$ & $\begin{array}{l}\text { excellent and good }=1 ; \text { fair, poor } \\
\text { or very poor }=0\end{array}$ \\
\hline \multicolumn{2}{|l|}{ Sex } & Interviewer checks sex of the respondent. & male $=1 ;$ female $=0$ \\
\hline
\end{tabular}


Table I. Continued

\begin{tabular}{|c|c|c|}
\hline Variable & Description & Value \\
\hline Age & $\begin{array}{l}\text { Derived variable: uses date of birth variables } \\
\text { on survey database. }\end{array}$ & age at date of interview \\
\hline Marital status & $\begin{array}{l}\text { Married, separated, divorced, widowed or } \\
\text { never married. }\end{array}$ & $\begin{array}{l}\text { married }=1 ; \text { separated, divorced, widowed or } \\
\text { never married }=0\end{array}$ \\
\hline Has child(ren) & $\begin{array}{l}\text { Number of own children derived from a set } \\
\text { of questions. }\end{array}$ & one, two, three or more kids $=1 ;$ none $=0$ \\
\hline Education & $\begin{array}{l}\text { Derived variable - yearly updated } \\
\text { qualification of new entrants and existing } \\
\text { panel members. }\end{array}$ & $\begin{array}{l}\text { no qualification }=1 ; \text { commercial qualification, no } \\
\text { o-levels, CSE grade } 2-5 \text { or Scotland grade } 4-5= \\
2 ; \text { GCE A-levels, GCE o-levels or equivalent = } \\
3 \text {; teaching , other higher or nursing } \\
\text { qualifications = 4; and first or higher degree }=5\end{array}$ \\
\hline Economic activity & $\begin{array}{l}\text { Please look at this card and tell me which } \\
\text { best describes your current situation? Self- } \\
\text { employed, in paid employment, unemployed, } \\
\text { retired, family care, FT student, long term } \\
\text { sick/disabled, on maternity leave, } \\
\text { government training or other. }\end{array}$ & $\begin{array}{l}\text { Unemployed, maternity leave, family care, full } \\
\text { time student, sick, disabled, government training } \\
\text { scheme, or other }=1 ; \text { retired }=2 ; \text { self- } \\
\text { employed }=3 ; \text { and employed }=4\end{array}$ \\
\hline Government office region & Internally computed. & $\begin{array}{l}\text { North East }=1 ; \text { North West }=2 ; \text { Yorkshire and } \\
\text { Humber }=3 ; \text { East Midlands }=4 ; \text { West Midlands } \\
=5 ; \text { East of England }=6 ; \text { London }=7 ; \text { South } \\
\text { East }=8 ; \text { South West }=9 ; \text { Wales }=10 ; \text { Scotland } \\
=11 ; \text { Northern Ireland = } 12 ; \text { and Channel } \\
\text { Islands = } 13\end{array}$ \\
\hline Income & $\begin{array}{l}\text { Derived variable that sums up all sources of } \\
\text { income indicated by the respondent } \\
\text { including : labour income and non-labour } \\
\text { income. }\end{array}$ & \\
\hline
\end{tabular}


Table II. Summary statistics

Data are derived from three waves of the BHPS: 1995, 2000 and 2005. The reported statistics for the whole sample are weighted and are as defined in Table I. Panel A presents proportion of respondents who invest directly in the stock market; invest through unit trust; hold individual savings accounts; have personal equity plans; invest in national savings bank; and invest in premium bonds. Panel B presents proportion of respondents who: (1) invest directly in the stock market or through unit trusts (stock market participation definition 1(SMP1)); (2) invest directly in the stock market, through unit trusts, personal equity plans, or individual savings accounts (SMP2); (3) invest in national savings certificate, premium bonds, national savings bonds, savings account, national savings bank, or other investments; and number of these products; and (4) the number of these products held by a respondent (NIP). Panel C presents the fraction of respondents who talk to neighbours, are active in social groups, trust most people, do not have political party affiliation, belong to various political parties, and have shifted their political affiliation during the panel period. Panel $D$ presents the proportion of respondents who rent, have a mortgage, or own outright their current accommodation; own a computer; received windfall income; have no debts; have good health, are male; are married; have child(ren); hold a first degree and above, other higher, GCE level, lower or no qualification; and who are employed, self-employed, retired or are unemployed. In addition, Panel B presents average income, age, cohort, and financial capability index.

\begin{tabular}{lcrr}
\hline Variable & Mean & Std. Dev. & Observations \\
\hline Panel A: Type of investment & & & \\
\hline Direct shareholding & 0.183 & 0.387 & 22407 \\
Unit trusts & 0.066 & 0.248 & 22407 \\
Individual Savings Account & 0.195 & 0.396 & 22583 \\
Personal Equity Plans & 0.111 & 0.314 & 22583 \\
Savings account & 0.630 & 0.483 & 14171 \\
National savings bank & 0.048 & 0.214 & 14171 \\
Premium bonds & 0.221 & 0.415 & 22407 \\
\hline Panel B: Dependent variables & & & \\
\hline SMP1 & 0.212 & 0.408 & 22583 \\
SMP2 & 0.351 & 0.477 & 22583 \\
Fixed interest assets (FIA) & 0.280 & 0.449 & 22583 \\
Number of investment products (NIP) & 3.951 & 3.464 & 22583 \\
\hline Panel C: Social engagement measures & & & \\
\hline Talking to neighbours & 0.928 & 0.259 & 21384 \\
Active in social groups & 0.487 & 0.500 & 22142 \\
Most people can be trusted & 0.378 & 0.485 & 21264 \\
Religion makes a difference & 0.434 & 0.496 & 20441 \\
No party affiliation & 0.115 & 0.319 & 20377 \\
Other smaller parties & 0.045 & 0.207 & 20377 \\
Liberal Democratic & 0.137 & 0.344 & 20377 \\
The Labour Party & 0.410 & 0.492 & 20377 \\
Conservative Party & 0.293 & 0.455 & 20377 \\
Political party shift & 0.381 & 0.486 & 22583 \\
\hline
\end{tabular}


Table II. Continued

\begin{tabular}{lrrr}
\hline Variable & Mean & Std. Dev. & Observations \\
\hline Panel D: Control variables & & & \\
\hline Rented & 0.252 & 0.434 & 22492 \\
Mortgaged & 0.451 & 0.498 & 22492 \\
Outright owner & 0.297 & 0.457 & 22492 \\
Computer user & 0.480 & 0.500 & 22515 \\
Received windfall income & 0.276 & 0.447 & 22515 \\
Has no debt & 0.644 & 0.479 & 22507 \\
Financial capability index & 0.003 & 0.582 & 22583 \\
Good health & 0.684 & 0.465 & 22579 \\
Male & 0.447 & 0.497 & 22583 \\
Cohort & 1950 & 18.202 & 22583 \\
Age at date of interview & 50 & 18.327 & 22583 \\
Married & 0.582 & 0.493 & 22579 \\
Has child(ren) & 0.270 & 0.444 & 22583 \\
No qualification & 0.262 & 0.440 & 22337 \\
Lower qualification & 0.088 & 0.283 & 22337 \\
GCE level qualification & 0.269 & 0.443 & 22337 \\
Other higher qualification & 0.262 & 0.440 & 22337 \\
First degree and above & 0.119 & 0.324 & 22337 \\
Unemployed & 0.178 & 0.383 & 22579 \\
Retired & 0.258 & 0.438 & 22579 \\
Self employed & 0.072 & 0.258 & 22579 \\
Employed & 0.492 & 0.500 & 22579 \\
Income & 13296 & 13731.4 & 22286 \\
\hline
\end{tabular}




\section{Table III. Social engagement and stock market participation}

The table presents marginal effects from pooled probit regressions estimates. The dependent variable in all the regressions is the stock market participation dummy variable. The explanatory variables are as defined in Table I. Talking to neighbours equals one if respondent talks to neighbours every day, once in a week, or once in a month and the value zero if rarely or never. Active in social groups equals one for respondents who are active and zero otherwise. Trusts most people equals one if the response is 'most people can be trusted' and zero otherwise. Religion makes a difference equals one if response is 'some' or 'a great difference' and zero otherwise. Number of social groups is a categorical variable equal to 1 if respondent does not belong to any social group (base level); equals to 2, if respondent belongs to one number social groups; equals 3 , if respondents belongs to two number social groups; and equals to 4 , if respondent belongs to three number social groups or more. The control variables are good neighbourhood dummy; concentrated housing dummy; housing tenure indicators; received windfall income dummy; has no debt dummy; financial capability index; good health dummy; male dummy; age; age squared; cohort; married dummy; has children dummy; education qualification indicators; economic activity indicators; Government office region indicators; and income quintile indicators. Panel A presents marginal effects at means. Panel B presents marginal effects at base characteristics. Base characteristics represent an individual who: does not talk to neighbours; is not active in social groups; can't be too careful - does not trust others; believes that religion makes little or no difference in life; has no political identification; rents current accommodation; has not received windfall income; has debt; has a financial capability index value equal to the mean; is not a computer user; has bad health; is a female; is not married; does not have children; has no educational qualification; is unemployed; lives in the North East of England; and is categorised in the 1st income quintile. Panel $\mathrm{C}$ presents marginal effects using varied characteristics. Unlike base characteristics, varied characteristics take the maximum values of each variable, apart from region, which becomes East of England. Panel D shows the increasing/(decreasing) joint marginal effect on stock market participation as each social engagement measure is included in the calculation, keeping the remaining measures at their base levels. The reference person for our calculation of joint marginal effects exhibits the varied characteristics previously described for Panel $\mathrm{C}$ above and, in addition, cumulatively adds the four social engagement measures, beginning with talking to neighbours. For example, in specification (5) row (1), we first evaluate the effect of talking to neighbours and then evaluate the marginal effects of both talking to neighbours and active in social groups in row (2), holding the other social engagement measures at their base levels and using the reference person characteristics. Standard errors are clustered at the individual level and are reported in parentheses. The levels of significance are given by * for $10 \%,{ }^{* *}$ for $5 \%$ and ${ }^{* * *}$ for $1 \%$. 
Table III. Continued

\begin{tabular}{|c|c|c|c|c|c|c|c|}
\hline Independent variables & (1) & (2) & (3) & $(4)$ & (5) & (6) & (7) \\
\hline \multicolumn{8}{|c|}{ Panel A: Marginal effects at means } \\
\hline Talking to neighbours & $\begin{array}{l}-0.0001 \\
(0.0104)\end{array}$ & & & & $\begin{array}{l}-0.0031 \\
(0.0107)\end{array}$ & $\begin{array}{l}-0.0056 \\
(0.0112)\end{array}$ & $\begin{array}{c}0.0082 \\
(0.0132)\end{array}$ \\
\hline Active in social groups & & $\begin{array}{c}0.0403^{* * *} \\
(0.0051)\end{array}$ & & & $\begin{array}{l}0.0405^{* * *} \\
(0.0051)\end{array}$ & $\begin{array}{c}0.0377^{* * *} \\
(0.0053)\end{array}$ & \\
\hline Trusts most people & & & $\begin{array}{l}0.0313^{* * *} \\
(0.0055)\end{array}$ & & & $\begin{array}{l}0.0280^{* * *} \\
(0.0057)\end{array}$ & $\begin{array}{c}0.0284^{* * *} \\
(0.0064)\end{array}$ \\
\hline Religion makes a difference & & & & $\begin{array}{c}-0.0193^{* * *} \\
(0.0057)\end{array}$ & & $\begin{array}{l}-0.0132^{* *} \\
(0.0057)\end{array}$ & $\begin{array}{l}-0.0126^{*} \\
(0.0064)\end{array}$ \\
\hline \multicolumn{8}{|l|}{$\begin{array}{l}\text { No of social groups } \\
\text { (Base=None) }\end{array}$} \\
\hline One & & & & & & & $\begin{array}{c}0.0291^{* * *} \\
(0.0068)\end{array}$ \\
\hline Two & & & & & & & $\begin{array}{l}0.0546^{* * *} \\
(0.0097)\end{array}$ \\
\hline Three & & & & & & & $\begin{array}{c}0.0889^{* * *} \\
(0.0134)\end{array}$ \\
\hline Good neighbourhood & $\begin{array}{l}0.0239 * * * \\
(0.0084)\end{array}$ & $\begin{array}{l}0.0203^{* *} \\
(0.0085)\end{array}$ & $\begin{array}{l}0.0203^{* *} \\
(0.0085)\end{array}$ & $\begin{array}{l}0.0239^{* * *} \\
(0.0089)\end{array}$ & $\begin{array}{l}0.0203^{* *} \\
(0.0086)\end{array}$ & $\begin{array}{l}0.0186^{* *} \\
(0.0090)\end{array}$ & $\begin{array}{l}0.0179^{*} \\
(0.0108)\end{array}$ \\
\hline Concentrated housing & $\begin{array}{l}-0.0032 \\
(0.0091)\end{array}$ & $\begin{array}{l}-0.0051 \\
(0.0092)\end{array}$ & $\begin{array}{l}-0.0033 \\
(0.0091)\end{array}$ & $\begin{array}{l}-0.0017 \\
(0.0096)\end{array}$ & $\begin{array}{l}-0.0053 \\
(0.0092)\end{array}$ & $\begin{array}{l}-0.0031 \\
(0.0096)\end{array}$ & $\begin{array}{l}-0.0066 \\
(0.0110)\end{array}$ \\
\hline \multicolumn{8}{|l|}{$\begin{array}{l}\text { Housing Tenure } \\
\text { (Base=rented) }\end{array}$} \\
\hline Mortgaged & $\begin{array}{l}0.0878^{* * *} \\
(0.0070)\end{array}$ & $\begin{array}{l}0.0885^{\star * *} \\
(0.0072)\end{array}$ & $\begin{array}{l}0.0879^{* * *} \\
(0.0070)\end{array}$ & $\begin{array}{l}0.0948^{* * *} \\
(0.0074)\end{array}$ & $\begin{array}{l}0.0888^{* * *} \\
(0.0071)\end{array}$ & $\begin{array}{c}0.0947^{* * *} \\
(0.0074)\end{array}$ & $\begin{array}{c}0.0751^{* * *} \\
(0.0083)\end{array}$ \\
\hline Outright owner & $\begin{array}{l}0.1615^{* * *} \\
(0.0083)\end{array}$ & $\begin{array}{l}0.1625^{\star * *} \\
(0.0084)\end{array}$ & $\begin{array}{l}0.1606^{* * *} \\
(0.0083)\end{array}$ & $\begin{array}{l}0.1686^{* * *} \\
(0.0086)\end{array}$ & $\begin{array}{l}0.1627^{* * *} \\
(0.0084)\end{array}$ & $\begin{array}{l}0.1670^{* * *} \\
(0.0086)\end{array}$ & $\begin{array}{c}0.1437^{* * *} \\
(0.0096)\end{array}$ \\
\hline Received windfall income & $\begin{array}{c}0.0397^{* * *} \\
(0.0058)\end{array}$ & $\begin{array}{l}0.0366^{* * *} \\
(0.0058)\end{array}$ & $\begin{array}{l}0.0400^{* * *} \\
(0.0058)\end{array}$ & $\begin{array}{l}0.0390^{* * *} \\
(0.0061)\end{array}$ & $\begin{array}{c}0.0367^{* * *} \\
(0.0058)\end{array}$ & $\begin{array}{c}0.0382^{* * *} \\
(0.0061)\end{array}$ & $\begin{array}{c}0.0399^{* * *} \\
(0.0073)\end{array}$ \\
\hline
\end{tabular}




\begin{tabular}{|c|c|c|c|c|c|c|c|}
\hline Independent variables & (1) & (2) & (3) & (4) & (5) & (6) & (7) \\
\hline Has no debt & $\begin{array}{c}0.0317^{* * *} \\
(0.0055)\end{array}$ & $\begin{array}{c}0.0324^{* * *} \\
(0.0056)\end{array}$ & $\begin{array}{l}0.0311^{* * *} \\
(0.0055)\end{array}$ & $\begin{array}{c}0.0346^{* * *} \\
(0.0058)\end{array}$ & $\begin{array}{c}0.0325^{* * *} \\
(0.0056)\end{array}$ & $\begin{array}{c}0.0344^{* * *} \\
(0.0058)\end{array}$ & $\begin{array}{c}0.0342^{* * *} \\
(0.0066)\end{array}$ \\
\hline Financial capability index & $\begin{array}{l}0.0958^{* * *} \\
(0.0085)\end{array}$ & $\begin{array}{l}0.0961^{* * *} \\
(0.0086)\end{array}$ & $\begin{array}{l}0.0952^{* * *} \\
(0.0085)\end{array}$ & $\begin{array}{c}0.0988^{* * *} \\
(0.0090)\end{array}$ & $\begin{array}{c}0.0963^{* * *} \\
(0.0086)\end{array}$ & $\begin{array}{c}0.0977^{* * *} \\
(0.0090)\end{array}$ & $\begin{array}{c}0.0855^{* * *} \\
(0.0101)\end{array}$ \\
\hline Computer user & $\begin{array}{c}0.0352^{* * *} \\
(0.0060)\end{array}$ & $\begin{array}{c}0.0329^{* * *} \\
(0.0061)\end{array}$ & $\begin{array}{c}0.0333^{* * *} \\
(0.0060)\end{array}$ & $\begin{array}{c}0.0368^{* * *} \\
(0.0063)\end{array}$ & $\begin{array}{c}0.0332^{* * *} \\
(0.0061)\end{array}$ & $\begin{array}{c}0.0343^{* * *} \\
(0.0064)\end{array}$ & $\begin{array}{c}0.0256^{* * *} \\
(0.0075)\end{array}$ \\
\hline Good health & $\begin{array}{c}0.0171^{* * *} \\
(0.0058)\end{array}$ & $\begin{array}{l}0.0149^{* *} \\
(0.0059)\end{array}$ & $\begin{array}{l}0.0154^{* * *} \\
(0.0059)\end{array}$ & $\begin{array}{c}0.0182^{* * *} \\
(0.0061)\end{array}$ & $\begin{array}{l}0.0147^{* *} \\
(0.0059)\end{array}$ & $\begin{array}{l}0.0150^{* *} \\
(0.0061)\end{array}$ & $\begin{array}{l}0.0167^{* *} \\
(0.0070)\end{array}$ \\
\hline Male & $\begin{array}{c}0.0166^{* * *} \\
(0.0061)\end{array}$ & $\begin{array}{c}0.0168^{* * *} \\
(0.0062)\end{array}$ & $\begin{array}{l}0.0169^{* * *} \\
(0.0061)\end{array}$ & $\begin{array}{c}0.0215^{\star * *} \\
(0.0065)\end{array}$ & $\begin{array}{c}0.0169^{* * *} \\
(0.0062)\end{array}$ & $\begin{array}{c}0.0221^{* * *} \\
(0.0065)\end{array}$ & $\begin{array}{c}0.0270^{* * *} \\
(0.0070)\end{array}$ \\
\hline Age & $\begin{array}{c}0.0047^{* * *} \\
(0.0013)\end{array}$ & $\begin{array}{c}0.0049^{* * *} \\
(0.0013)\end{array}$ & $\begin{array}{c}0.0045^{* * *} \\
(0.0013)\end{array}$ & $\begin{array}{c}0.0036^{* * *} \\
(0.0014)\end{array}$ & $\begin{array}{l}0.0050^{* * *} \\
(0.0013)\end{array}$ & $\begin{array}{l}0.0037^{* * *} \\
(0.0014)\end{array}$ & $\begin{array}{c}0.0049^{* * *} \\
(0.0015)\end{array}$ \\
\hline Age square & $\begin{array}{c}-0.0001^{* * *} \\
(0.0000)\end{array}$ & $\begin{array}{c}-0.0001^{* * *} \\
(0.0000)\end{array}$ & $\begin{array}{c}-0.0001^{* * *} \\
(0.0000)\end{array}$ & $\begin{array}{c}-0.0001^{* * *} \\
(0.0000)\end{array}$ & $\begin{array}{c}-0.0001^{* * *} \\
(0.0000)\end{array}$ & $\begin{array}{c}-0.0001^{* * *} \\
(0.0000)\end{array}$ & $\begin{array}{c}-0.0001^{* * *} \\
(0.0000)\end{array}$ \\
\hline cohort & $\begin{array}{c}-0.0091^{* * *} \\
(0.0006)\end{array}$ & $\begin{array}{c}-0.0088^{* * *} \\
(0.0007)\end{array}$ & $\begin{array}{c}-0.0087^{\star * \star} \\
(0.0007)\end{array}$ & $\begin{array}{c}-0.0095^{\star * *} \\
(0.0007)\end{array}$ & $\begin{array}{c}-0.0088^{* \star *} \\
(0.0007)\end{array}$ & $\begin{array}{c}-0.0090^{\star * \star} \\
(0.0007)\end{array}$ & $\begin{array}{c}-0.0068^{* * *} \\
(0.0007)\end{array}$ \\
\hline Married & $\begin{array}{l}0.0161^{\star *} \\
(0.0063)\end{array}$ & $\begin{array}{l}0.0155^{\star *} \\
(0.0064)\end{array}$ & $\begin{array}{l}0.0150^{* *} \\
(0.0063)\end{array}$ & $\begin{array}{l}0.0133^{* *} \\
(0.0067)\end{array}$ & $\begin{array}{l}0.0155^{\star *} \\
(0.0064)\end{array}$ & $\begin{array}{l}0.0118^{*} \\
(0.0067)\end{array}$ & $\begin{array}{c}0.0049 \\
(0.0073)\end{array}$ \\
\hline Has child(ren) & $\begin{array}{c}-0.0216^{\star \star \star} \\
(0.0066)\end{array}$ & $\begin{array}{c}-0.0216^{\star * *} \\
(0.0066)\end{array}$ & $\begin{array}{c}-0.0214^{* \star *} \\
(0.0066)\end{array}$ & $\begin{array}{c}-0.0238^{* * *} \\
(0.0070)\end{array}$ & $\begin{array}{c}-0.0212^{\star \star \star} \\
(0.0066)\end{array}$ & $\begin{array}{c}-0.0240^{* * *} \\
(0.0070)\end{array}$ & $\begin{array}{c}-0.0176^{* *} \\
(0.0078)\end{array}$ \\
\hline \multicolumn{8}{|l|}{$\begin{array}{l}\text { Education qualification } \\
\text { (Base=None) }\end{array}$} \\
\hline Lower level & $\begin{array}{l}0.0486^{* * *} \\
(0.0100)\end{array}$ & $\begin{array}{l}0.0492^{* * *} \\
(0.0103)\end{array}$ & $\begin{array}{l}0.0482^{* * *} \\
(0.0101)\end{array}$ & $\begin{array}{l}0.0522^{* * *} \\
(0.0106)\end{array}$ & $\begin{array}{l}0.0489^{* * *} \\
(0.0103)\end{array}$ & $\begin{array}{l}0.0500^{* * *} \\
(0.0108)\end{array}$ & $\begin{array}{l}0.0479^{* * *} \\
(0.0120)\end{array}$ \\
\hline GCE level & $\begin{array}{l}0.1023^{* * *} \\
(0.0077)\end{array}$ & $\begin{array}{l}0.0983^{* * *} \\
(0.0079)\end{array}$ & $\begin{array}{l}0.1007^{* * *} \\
(0.0078)\end{array}$ & $\begin{array}{l}0.1040^{* * *} \\
(0.0082)\end{array}$ & $\begin{array}{l}0.0981^{* * *} \\
(0.0079)\end{array}$ & $\begin{array}{l}0.0988^{* * *} \\
(0.0083)\end{array}$ & $\begin{array}{l}0.0823^{* * *} \\
(0.0090)\end{array}$ \\
\hline Other higher & $\begin{array}{l}0.1179^{* * *} \\
(0.0081)\end{array}$ & $\begin{array}{l}0.1108^{* * *} \\
(0.0083)\end{array}$ & $\begin{array}{l}0.1147^{* * *} \\
(0.0082)\end{array}$ & $\begin{array}{l}0.1172^{* * *} \\
(0.0085)\end{array}$ & $\begin{array}{l}0.1107^{* * *} \\
(0.0083)\end{array}$ & $\begin{array}{l}0.1085^{* * *} \\
(0.0086)\end{array}$ & $\begin{array}{l}0.0870^{* * *} \\
(0.0093)\end{array}$ \\
\hline $\begin{array}{l}\text { First degree and } \\
\text { above }\end{array}$ & $0.1737^{* * *}$ & $0.1640^{* * *}$ & $0.1644^{* * *}$ & $0.1733^{\star \star \star}$ & $0.1636^{\star \star \star}$ & $0.1558^{\star \star \star}$ & $0.1419^{* * *}$ \\
\hline & $(0.0112)$ & $(0.0114)$ & $(0.0113)$ & $(0.0117)$ & $(0.0114)$ & $(0.0118)$ & $(0.0130)$ \\
\hline
\end{tabular}


Table III. Continued

\begin{tabular}{|c|c|c|c|c|c|c|c|}
\hline Independent variables & (1) & $(2)$ & (3) & (4) & (5) & (6) & (7) \\
\hline \multicolumn{8}{|l|}{$\begin{array}{l}\text { Economic Activity } \\
\text { (Base=Unemployed) }\end{array}$} \\
\hline Retired & $\begin{array}{l}0.0577^{* * *} \\
(0.0121)\end{array}$ & $\begin{array}{l}0.0589^{* * *} \\
(0.0122)\end{array}$ & $\begin{array}{l}0.0544^{* * *} \\
(0.0121)\end{array}$ & $\begin{array}{l}0.0613^{* * *} \\
(0.0126)\end{array}$ & $\begin{array}{l}0.0593^{* * *} \\
(0.0122)\end{array}$ & $\begin{array}{c}0.0589^{* * *} \\
(0.0126)\end{array}$ & $\begin{array}{c}0.0466^{* * *} \\
(0.0139)\end{array}$ \\
\hline Self employed & $\begin{array}{l}0.0075 \\
(0.0118)\end{array}$ & $\begin{array}{c}0.0087 \\
(0.0119)\end{array}$ & $\begin{array}{c}0.0056 \\
(0.0118)\end{array}$ & $\begin{array}{c}0.0071 \\
(0.0123)\end{array}$ & $\begin{array}{c}0.0090 \\
(0.0119)\end{array}$ & $\begin{array}{c}0.0071 \\
(0.0124)\end{array}$ & $\begin{array}{c}0.0147 \\
(0.0138)\end{array}$ \\
\hline Employed & $\begin{array}{l}-0.0019 \\
(0.0086)\end{array}$ & $\begin{array}{l}-0.0010 \\
(0.0087)\end{array}$ & $\begin{array}{l}-0.0037 \\
(0.0086)\end{array}$ & $\begin{array}{l}-0.0022 \\
(0.0091)\end{array}$ & $\begin{array}{l}-0.0005 \\
(0.0087)\end{array}$ & $\begin{array}{l}-0.0023 \\
(0.0091)\end{array}$ & $\begin{array}{c}0.0012 \\
(0.0104)\end{array}$ \\
\hline \multicolumn{8}{|l|}{ Region (Base $=$ North East) } \\
\hline North West & $\begin{array}{c}0.0499^{* * *} \\
(0.0175)\end{array}$ & $\begin{array}{c}0.0513^{* * *} \\
(0.0176)\end{array}$ & $\begin{array}{c}0.0498^{* * *} \\
(0.0175)\end{array}$ & $\begin{array}{l}0.0507^{* * *} \\
(0.0182)\end{array}$ & $\begin{array}{l}0.0511^{* * *} \\
(0.0177)\end{array}$ & $\begin{array}{l}0.0489^{* * *} \\
(0.0184)\end{array}$ & $\begin{array}{r}0.0524^{\star * *} \\
(0.0199)\end{array}$ \\
\hline Yorkshire \& Humber & $\begin{array}{l}0.0490^{* * *} \\
(0.0183)\end{array}$ & $\begin{array}{l}0.0536^{* * *} \\
(0.0185)\end{array}$ & $\begin{array}{l}0.0509^{* * *} \\
(0.0183)\end{array}$ & $\begin{array}{l}0.0523^{* * *} \\
(0.0191)\end{array}$ & $\begin{array}{l}0.0526^{* * *} \\
(0.0185)\end{array}$ & $\begin{array}{l}0.0524^{* * *} \\
(0.0192)\end{array}$ & $\begin{array}{l}0.0413^{* *} \\
(0.0208)\end{array}$ \\
\hline East Midlands & $\begin{array}{l}0.0498^{* * *} \\
(0.0189)\end{array}$ & $\begin{array}{l}0.0534^{* * *} \\
(0.0190)\end{array}$ & $\begin{array}{l}0.0507^{* * *} \\
(0.0189)\end{array}$ & $\begin{array}{l}0.0521^{* * *} \\
(0.0197)\end{array}$ & $\begin{array}{l}0.0533^{* * *} \\
(0.0191)\end{array}$ & $\begin{array}{l}0.0523^{* * *} \\
(0.0199)\end{array}$ & $\begin{array}{l}0.0575^{* * *} \\
(0.0214)\end{array}$ \\
\hline West Midlands & $\begin{array}{l}0.0319^{*} \\
(0.0180)\end{array}$ & $\begin{array}{l}0.0308^{*} \\
(0.0181)\end{array}$ & $\begin{array}{l}0.0323^{*} \\
(0.0181)\end{array}$ & $\begin{array}{l}0.0337^{*} \\
(0.0188)\end{array}$ & $\begin{array}{l}0.0306^{*} \\
(0.0181)\end{array}$ & $\begin{array}{c}0.0302 \\
(0.0189)\end{array}$ & $\begin{array}{l}0.0442^{* *} \\
(0.0207)\end{array}$ \\
\hline East of England & $\begin{array}{l}0.1146^{* * *} \\
(0.0188)\end{array}$ & $\begin{array}{l}0.1170^{* * *} \\
(0.0189)\end{array}$ & $\begin{array}{l}0.1146^{* * *} \\
(0.0189)\end{array}$ & $\begin{array}{l}0.1159^{* * *} \\
(0.0197)\end{array}$ & $\begin{array}{l}0.1170^{* * *} \\
(0.0190)\end{array}$ & $\begin{array}{l}0.1156^{* * *} \\
(0.0198)\end{array}$ & $\begin{array}{l}0.1186^{* * *} \\
(0.0218)\end{array}$ \\
\hline London & $\begin{array}{l}0.1007^{* * *} \\
(0.0191)\end{array}$ & $\begin{array}{l}0.1028^{* * *} \\
(0.0193)\end{array}$ & $\begin{array}{c}0.1024^{* * *} \\
(0.0192)\end{array}$ & $\begin{array}{c}0.1070^{* * *} \\
(0.0200)\end{array}$ & $\begin{array}{c}0.1021^{* * *} \\
(0.0193)\end{array}$ & $\begin{array}{l}0.1051^{* * *} \\
(0.0202)\end{array}$ & $\begin{array}{c}0.1106^{* * *} \\
(0.0219)\end{array}$ \\
\hline South East & $\begin{array}{c}0.0758^{* * *} \\
(0.0172)\end{array}$ & $\begin{array}{c}0.0779^{* * *} \\
(0.0173)\end{array}$ & $\begin{array}{c}0.0747^{* * *} \\
(0.0171)\end{array}$ & $\begin{array}{c}0.0791^{* * *} \\
(0.0180)\end{array}$ & $\begin{array}{c}0.0777^{* * *} \\
(0.0173)\end{array}$ & $\begin{array}{c}0.0764^{* * *} \\
(0.0181)\end{array}$ & $\begin{array}{c}0.0814^{* * *} \\
(0.0198)\end{array}$ \\
\hline South West & $\begin{array}{c}0.0480^{* * *} \\
(0.0184)\end{array}$ & $\begin{array}{c}0.0510^{* * *} \\
(0.0186)\end{array}$ & $\begin{array}{c}0.0479^{* * *} \\
(0.0184)\end{array}$ & $\begin{array}{c}0.0524^{* * *} \\
(0.0193)\end{array}$ & $\begin{array}{c}0.0505^{* * *} \\
(0.0186)\end{array}$ & $\begin{array}{l}0.0491^{* *} \\
(0.0194)\end{array}$ & $\begin{array}{c}0.0596^{* * *} \\
(0.0212)\end{array}$ \\
\hline Wales & $\begin{array}{l}0.0369^{* *} \\
(0.0163)\end{array}$ & $\begin{array}{l}0.0389^{* *} \\
(0.0164)\end{array}$ & $\begin{array}{l}0.0365^{\star *} \\
(0.0163)\end{array}$ & $\begin{array}{l}0.0390^{* *} \\
(0.0170)\end{array}$ & $\begin{array}{l}0.0386^{* *} \\
(0.0164)\end{array}$ & $\begin{array}{l}0.0361^{* *} \\
(0.0172)\end{array}$ & $\begin{array}{c}0.0316^{\star} \\
(0.0191)\end{array}$ \\
\hline Scotland & $\begin{array}{c}0.0565^{* * *} \\
(0.0164)\end{array}$ & $\begin{array}{c}0.0596^{* * *} \\
(0.0165)\end{array}$ & $\begin{array}{c}0.0548^{* * *} \\
(0.0164)\end{array}$ & $\begin{array}{c}0.0596^{* * *} \\
(0.0171)\end{array}$ & $\begin{array}{c}0.0595^{* * *} \\
(0.0166)\end{array}$ & $\begin{array}{c}0.0556^{* * *} \\
(0.0173)\end{array}$ & $\begin{array}{c}0.0581^{* * *} \\
(0.0193)\end{array}$ \\
\hline Northern Ireland & $\begin{array}{c}-0.0401^{* *} \\
(0.0169)\end{array}$ & $\begin{array}{c}-0.0389^{* *} \\
(0.0170)\end{array}$ & $\begin{array}{c}-0.0397^{* *} \\
(0.0169)\end{array}$ & $\begin{array}{c}-0.0430 * * \\
(0.0176)\end{array}$ & $\begin{array}{c}-0.0391^{* *} \\
(0.0170)\end{array}$ & $\begin{array}{c}-0.0437^{* *} \\
(0.0177)\end{array}$ & $\begin{array}{c}-0.0094 \\
(0.0192)\end{array}$ \\
\hline
\end{tabular}




\begin{tabular}{|c|c|c|c|c|c|c|c|}
\hline Independent variables & (1) & $(2)$ & (3) & $(4)$ & $(5)$ & (6) & $(7)$ \\
\hline \multicolumn{8}{|l|}{$\begin{array}{l}\text { Income quintile (Base }=1^{\text {st }} \\
\text { quintile) }\end{array}$} \\
\hline $2^{\text {nd }}$. Income quintile & $\begin{array}{l}0.0142^{*} \\
(0.0077)\end{array}$ & $\begin{array}{l}0.0164^{* *} \\
(0.0078)\end{array}$ & $\begin{array}{l}0.0144^{*} \\
(0.0077)\end{array}$ & $\begin{array}{l}0.0148^{*} \\
(0.0082)\end{array}$ & $\begin{array}{l}0.0168^{* *} \\
(0.0078)\end{array}$ & $\begin{array}{l}0.0166^{* *} \\
(0.0082)\end{array}$ & $\begin{array}{l}0.0203^{* *} \\
(0.0094)\end{array}$ \\
\hline $3^{\text {rd }}$ Income quintile & $\begin{array}{c}0.0401^{* * *} \\
(0.0081)\end{array}$ & $\begin{array}{c}0.0436^{* * *} \\
(0.0082)\end{array}$ & $\begin{array}{c}0.0405^{\star * *} \\
(0.0082)\end{array}$ & $\begin{array}{c}0.0410^{\star * *} \\
(0.0086)\end{array}$ & $\begin{array}{c}0.0436^{* * *} \\
(0.0082)\end{array}$ & $\begin{array}{c}0.0422^{* \star *} \\
(0.0086)\end{array}$ & $\begin{array}{c}0.0355^{\star * *} \\
(0.0097)\end{array}$ \\
\hline $4^{\text {th }}$ Income quintile & $\begin{array}{c}0.0690^{* * *} \\
(0.0090)\end{array}$ & $\begin{array}{l}0.0699^{* * *} \\
(0.0091)\end{array}$ & $\begin{array}{l}0.0691^{* * *} \\
(0.0090)\end{array}$ & $\begin{array}{c}0.0683^{* * *} \\
(0.0095)\end{array}$ & $\begin{array}{c}0.0700^{* * *} \\
(0.0091)\end{array}$ & $\begin{array}{c}0.0677^{* * \star} \\
(0.0095)\end{array}$ & $\begin{array}{l}0.0606^{* * *} \\
(0.0106)\end{array}$ \\
\hline $5^{\text {th }}$ Income quintile & $\begin{array}{c}0.1279^{* * *} \\
(0.0106)\end{array}$ & $\begin{array}{c}0.1277^{* * *} \\
(0.0107)\end{array}$ & $\begin{array}{c}0.1261^{* * *} \\
(0.0106)\end{array}$ & $\begin{array}{c}0.1278^{* * *} \\
(0.0111)\end{array}$ & $\begin{array}{c}0.1275^{\star * *} \\
(0.0107)\end{array}$ & $\begin{array}{l}0.1243^{* * *} \\
(0.0110)\end{array}$ & $\begin{array}{l}0.1092^{* * *} \\
(0.0122)\end{array}$ \\
\hline Pseudo $r^{2}$ & 0.1557 & 0.1575 & 0.1573 & 0.1538 & 0.1577 & 0.1576 & 0.1604 \\
\hline Observations & 25810 & 25246 & 25676 & 24114 & 25235 & 23916 & 14993 \\
\hline \multicolumn{8}{|c|}{ Panel B: Marginal effects at base characteristics } \\
\hline Talking to neighbours & $\begin{array}{l}-0.0000 \\
(0.0005\end{array}$ & & & & $\begin{array}{l}-0.0002 \\
(0.0007)\end{array}$ & $\begin{array}{l}-0.0004 \\
(0.0009)\end{array}$ & $\begin{array}{c}0.0008 \\
(0.0013)\end{array}$ \\
\hline Active in social groups & & $\begin{array}{r}0.0021^{* *} \\
(0.0006)\end{array}$ & & & $\begin{array}{l}0.0021^{* * *} \\
(0.0006)\end{array}$ & $\begin{array}{c}0.0024^{* * *} \\
(0.0007)\end{array}$ & \\
\hline Trusts most people & & & $\begin{array}{c}0.0018^{* * *} \\
(0.0006)\end{array}$ & & & $\begin{array}{l}0.0019^{* * *} \\
(0.0006)\end{array}$ & $\begin{array}{l}0.0025^{* *} \\
(0.0010)\end{array}$ \\
\hline Religion makes a difference & & & & $\begin{array}{c}-0.0009^{* * *} \\
(0.0004)\end{array}$ & & $\begin{array}{c}-0.0011^{* *} \\
(0.0005)\end{array}$ & $\begin{array}{l}-0.0014^{*} \\
(0.0008)\end{array}$ \\
\hline \multicolumn{8}{|c|}{ No of social groups (Base=None) } \\
\hline One & & & & & & & $\begin{array}{l}0.0015^{\star *} \\
(0.0006)\end{array}$ \\
\hline Two & & & & & & & $\begin{array}{l}0.0030^{* *} \\
(0.0012)\end{array}$ \\
\hline Three & & & & & & & $\begin{array}{r}0.0057^{* * *} \\
(0.0022)\end{array}$ \\
\hline
\end{tabular}


Table III continued

\begin{tabular}{|c|c|c|c|c|c|c|c|}
\hline Independent variables & & (1) & (2) & (3) & (4) & (5) & (6) \\
\hline \multicolumn{8}{|c|}{ Panel C: Marginal effects at varied characteristics } \\
\hline Talking to neighbours & $\begin{array}{l}-0.0002 \\
(0.0159)\end{array}$ & & & & $\begin{array}{l}-0.0046 \\
(0.0159)\end{array}$ & $\begin{array}{l}-0.0081 \\
(0.0161)\end{array}$ & $\begin{array}{l}0.0127 \\
(0.0209)\end{array}$ \\
\hline Active in social groups & & $\begin{array}{c}0.0623^{* * *} \\
(0.0081)\end{array}$ & & & $\begin{array}{l}0.0625^{* * *} \\
(0.0081)\end{array}$ & $\begin{array}{l}0.0569^{* * *} \\
(0.0082)\end{array}$ & \\
\hline Trusts most people & & & $\begin{array}{c}0.0476^{* * *} \\
(0.0084)\end{array}$ & & & $\begin{array}{l}0.0417^{* * *} \\
(0.0086)\end{array}$ & $\begin{array}{c}0.0438^{\star \star \star} \\
(0.0103)\end{array}$ \\
\hline Religion makes a difference & & & & $\begin{array}{c}-0.0290^{* * *} \\
(0.0086)\end{array}$ & & $\begin{array}{l}-0.0192^{* *} \\
(0.0084)\end{array}$ & $\begin{array}{l}-0.0187^{*} \\
(0.0098)\end{array}$ \\
\hline No of social groups (Base $=$ None) & & & & & & & \\
\hline One & & & & & & & $\begin{array}{c}0.0506^{* * *} \\
(0.0118)\end{array}$ \\
\hline Two & & & & & & & $\begin{array}{c}0.0896^{* \star \star} \\
(0.0153)\end{array}$ \\
\hline Three & & & & & & & $\begin{array}{c}0.1359^{* * *} \\
(0.0187)\end{array}$ \\
\hline Observations & 25810 & 25246 & 25676 & 24114 & 25235 & 23916 & 14993 \\
\hline \multicolumn{8}{|c|}{ Panel D: Joint Marginal effects at means } \\
\hline Talking to neighbours & & & & & $\begin{array}{l}-0.0026 \\
(0.0090)\end{array}$ & $\begin{array}{l}-0.0045 \\
(0.0089)\end{array}$ & $\begin{array}{c}0.0069 \\
(0.0112)\end{array}$ \\
\hline $\begin{array}{l}\text { + Active in social } \\
\text { groups }\end{array}$ & & & & & $\begin{array}{l}0.0327^{* * *} \\
(0.0103)\end{array}$ & $\begin{array}{l}0.0266^{* * *} \\
(0.0102)\end{array}$ & \\
\hline $\begin{array}{l}+ \text { Three or more social } \\
\text { groups }\end{array}$ & & & & & & & $\begin{array}{c}0.0823^{\star \star *} \\
(0.0173)\end{array}$ \\
\hline + Trusts most people & & & & & & $\begin{array}{l}0.0507^{* * *} \\
(0.0114)\end{array}$ & $\begin{array}{l}0.1103^{* \star *} \\
(0.0190)\end{array}$ \\
\hline $\begin{array}{l}\text { + Religion makes a } \\
\text { difference }\end{array}$ & & & & & & $\begin{array}{l}0.0391^{* * *} \\
(0.0124)\end{array}$ & $\begin{array}{l}0.0976^{* \star *} \\
(0.0197)\end{array}$ \\
\hline Observations & 25810 & 25246 & 25676 & 24114 & 25235 & 23916 & 14993 \\
\hline
\end{tabular}


Table IV. Political party identification, social engagement and stock market participation

The table presents marginal effects from pooled probit regressions estimates. Panel A presents marginal effects at means, Panel B marginal effects at base characteristics; Panel $C$ marginal effects using varied characteristics; and Panel $D$ joint marginal effects. The dependent variable in all the regressions is the stock market participation dummy variable. Explanatory variables are as defined in Table I. Political party identification is a categorical variable and is equals one if the respondent has no political affiliation (base level); equals two ifaffiliated with other smaller parties; equals three if affiliated with the Liberal Democratic Party; equals four if affiliated with the Labour Party; and equals five if affiliated with the Conservative Party. Talking to neighbours equals one if respondent talks to neighbours every day, once in a week, or once in a month and the value zero if rarely or never. Active in social groups equals one for respondents who are active and zero otherwise. Trusts most people equals one if the response is 'most people can be trusted' and zero otherwise. Religion makes a difference equals one if the response is 'some' or 'a great difference' and zero otherwise. Number of social groups is a categorical variable equal to 1 if the respondent does not belong to any social group (base level); equal to 2, if the respondent belongs to one social group; equal to 3 if the respondent belongs to two social groups; and equal to 4 if the respondent belongs to three social groups or more. The control variables are good neighbourhood dummy; concentrated housing dummy; housing tenure indicators; received windfall income dummy; has no debt dummy; financial capability index; good health dummy; male dummy; age; age squared; cohort; married dummy; has children dummy; education qualification indicators; economic activity indicators; Government office region indicators; and income quintile indicators. Standard errors are clustered at the individual level and are reported in parentheses. The base characteristics, varied characteristics and the reference person are defined in the legend of Table III. The levels of significance are given by ${ }^{*}$ for $10 \%$, ${ }^{* *}$ for $5 \%$ and ${ }^{* * *}$ for $1 \%$.

\begin{tabular}{|c|c|c|c|}
\hline Independent variable & (1) & $(2)$ & (3) \\
\hline \multicolumn{4}{|c|}{ Panel A: Marginal effects at means } \\
\hline Talking to neighbours & & $\begin{array}{c}-0.0079 \\
(0.0117)\end{array}$ & $\begin{array}{c}0.0092 \\
(0.0137)\end{array}$ \\
\hline Active in social groups & & $\begin{array}{c}0.0367^{* * *} \\
(0.0055)\end{array}$ & \\
\hline Trusts most people & & $\begin{array}{c}0.0279^{* \star *} \\
(0.0059)\end{array}$ & $\begin{array}{c}0.0277^{* * *} \\
(0.0067)\end{array}$ \\
\hline Religion makes a difference & & $\begin{array}{l}-0.0103^{*} \\
(0.0060)\end{array}$ & $\begin{array}{l}-0.0100 \\
(0.0067)\end{array}$ \\
\hline \multicolumn{4}{|c|}{ No of social groups (Base=None) } \\
\hline One & & & $\begin{array}{c}0.0295^{* * *} \\
(0.0071)\end{array}$ \\
\hline Two & & & $\begin{array}{c}0.0531^{* * *} \\
(0.0101)\end{array}$ \\
\hline Three or more & & & $\begin{array}{c}0.0892^{* * *} \\
(0.0137)\end{array}$ \\
\hline
\end{tabular}


Table IV. Continued

\begin{tabular}{|c|c|c|c|}
\hline Independent variables & (1) & $(2)$ & (3) \\
\hline \multicolumn{4}{|l|}{ Party identification (Base=None) } \\
\hline Other smaller parties & $\begin{array}{c}0.0184 \\
(0.0115)\end{array}$ & $\begin{array}{c}0.0159 \\
(0.0125)\end{array}$ & $\begin{array}{c}0.0168 \\
(0.0141)\end{array}$ \\
\hline Liberal Democratic & $\begin{array}{c}0.0588^{* * *} \\
(0.0110)\end{array}$ & $\begin{array}{c}0.0491^{* * *} \\
(0.0116)\end{array}$ & $\begin{array}{c}0.0431^{* * *} \\
(0.0133)\end{array}$ \\
\hline The Labour Party & $\begin{array}{l}0.0196^{\star *} \\
(0.0089)\end{array}$ & $\begin{array}{c}0.0152 \\
(0.0095)\end{array}$ & $\begin{array}{c}0.0105 \\
(0.0112)\end{array}$ \\
\hline Conservative Party & $\begin{array}{c}0.0888^{* * *} \\
(0.0100)\end{array}$ & $\begin{array}{c}0.0834^{* * *} \\
(0.0106)\end{array}$ & $\begin{array}{c}0.0803^{* * *} \\
(0.0124)\end{array}$ \\
\hline Good neighbourhood & $\begin{array}{c}0.0165^{*} \\
(0.0088)\end{array}$ & $\begin{array}{c}0.0111 \\
(0.0096)\end{array}$ & $\begin{array}{c}0.0085 \\
(0.0115)\end{array}$ \\
\hline Concentrated housing & $\begin{array}{c}0.0004 \\
(0.0094)\end{array}$ & $\begin{array}{c}0.0008 \\
(0.0100)\end{array}$ & $\begin{array}{c}-0.0069 \\
(0.0115)\end{array}$ \\
\hline Housing Tenure (Base=rented) & & & \\
\hline Mortgaged & $\begin{array}{c}0.0811^{* * *} \\
(0.0074)\end{array}$ & $\begin{array}{c}0.0884^{* * *} \\
(0.0078)\end{array}$ & $\begin{array}{c}0.0704^{* * *} \\
(0.0088)\end{array}$ \\
\hline Outright owner & $\begin{array}{c}0.1501^{* * *} \\
(0.0086)\end{array}$ & $\begin{array}{c}0.1564^{* * *} \\
(0.0090)\end{array}$ & $\begin{array}{c}0.1355^{* * *} \\
(0.0101)\end{array}$ \\
\hline Received windfall income & $\begin{array}{c}0.0361^{* * *} \\
(0.0061)\end{array}$ & $\begin{array}{c}0.0348^{* * *} \\
(0.0063)\end{array}$ & $\begin{array}{c}0.0350^{* * *} \\
(0.0075)\end{array}$ \\
\hline Has no debt & $\begin{array}{c}0.0318^{* * *} \\
(0.0058)\end{array}$ & $\begin{array}{c}0.0333^{* * *} \\
(0.0061)\end{array}$ & $\begin{array}{c}0.0337^{* * *} \\
(0.0069)\end{array}$ \\
\hline Financial capability index & $\begin{array}{c}0.0906^{* * *} \\
(0.0088)\end{array}$ & $\begin{array}{c}0.0924^{* * *} \\
(0.0093)\end{array}$ & $\begin{array}{c}0.0775^{* * *} \\
(0.0104)\end{array}$ \\
\hline Computer user & $\begin{array}{c}0.0366^{* * *} \\
(0.0063)\end{array}$ & $\begin{array}{c}0.0350^{* * *} \\
(0.0066)\end{array}$ & $\begin{array}{c}0.0253^{* * *} \\
(0.0078)\end{array}$ \\
\hline Good health & $\begin{array}{c}0.0164^{* * *} \\
(0.0061)\end{array}$ & $\begin{array}{l}0.0144^{* *} \\
(0.0064)\end{array}$ & $\begin{array}{l}0.0157^{* *} \\
(0.0073)\end{array}$ \\
\hline Male & $\begin{array}{c}0.0217^{* * *} \\
(0.0063)\end{array}$ & $\begin{array}{c}0.0278^{* * *} \\
(0.0067)\end{array}$ & $\begin{array}{c}0.0314^{* * *} \\
(0.0073)\end{array}$ \\
\hline Age & $\begin{array}{c}0.0050^{* * *} \\
(0.0013)\end{array}$ & $\begin{array}{c}0.0043^{* * *} \\
(0.0015)\end{array}$ & $\begin{array}{c}0.0055^{\star * *} \\
(0.0016)\end{array}$ \\
\hline Age square & $\begin{array}{c}-0.0001^{* * *} \\
(0.0000)\end{array}$ & $\begin{array}{c}-0.0001^{* * *} \\
(0.0000)\end{array}$ & $\begin{array}{c}-0.0001^{* * *} \\
(0.0000)\end{array}$ \\
\hline cohort & $\begin{array}{c}-0.0083^{* * *} \\
(0.0007)\end{array}$ & $\begin{array}{c}-0.0084^{* * *} \\
(0.0007)\end{array}$ & $\begin{array}{c}-0.0063^{* * *} \\
(0.0008)\end{array}$ \\
\hline Married & $\begin{array}{l}0.0143^{* *} \\
(0.0065)\end{array}$ & $\begin{array}{c}0.0109 \\
(0.0069)\end{array}$ & $\begin{array}{c}0.0046 \\
(0.0076)\end{array}$ \\
\hline Has child(ren) & $\begin{array}{c}-0.0198^{* * *} \\
(0.0069)\end{array}$ & $\begin{array}{c}-0.0220^{\star * *} \\
(0.0073)\end{array}$ & $\begin{array}{c}-0.0187^{* *} \\
(0.0082)\end{array}$ \\
\hline
\end{tabular}


Table IV. Continued

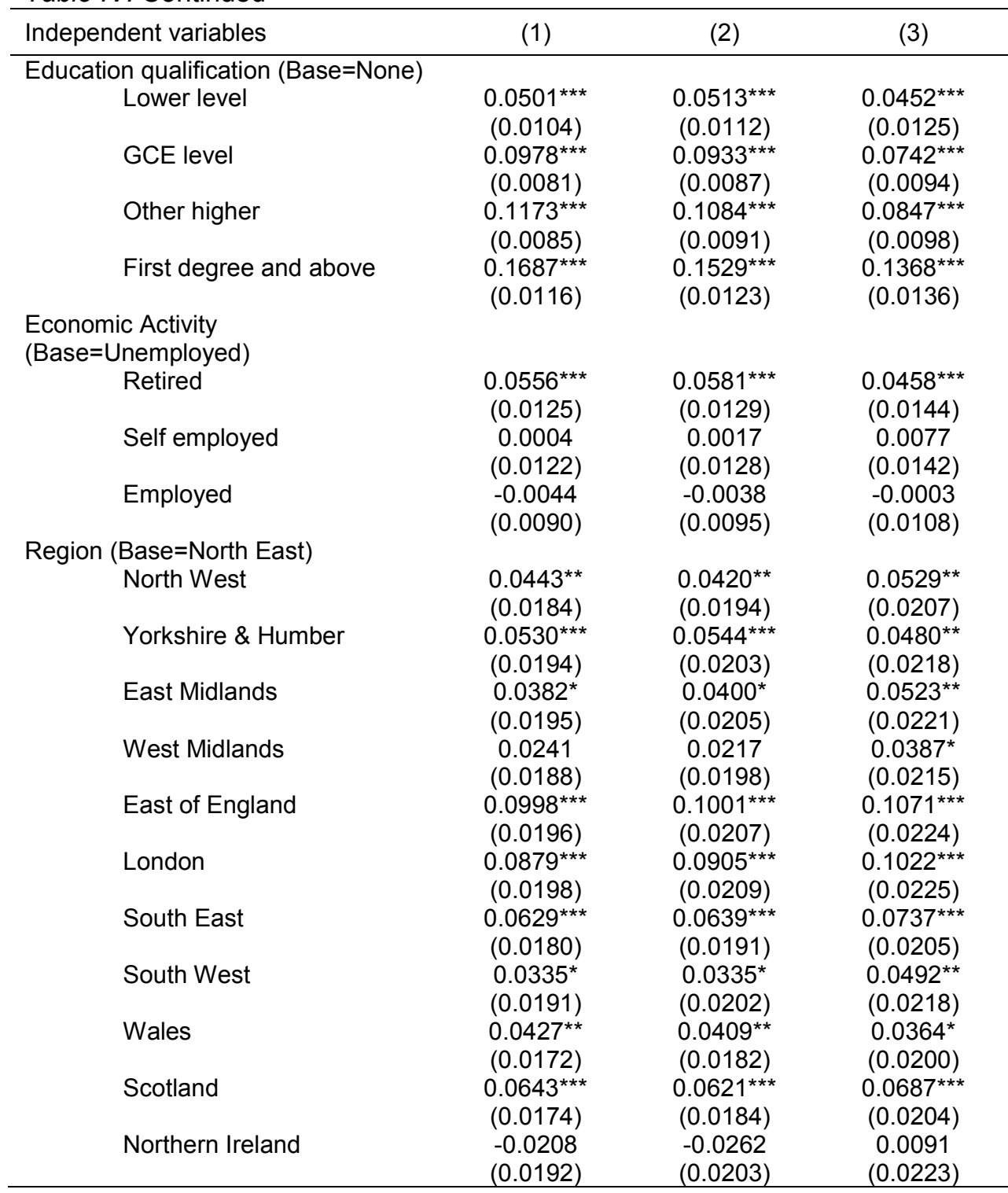


Table IV. Continued

\begin{tabular}{|c|c|c|c|}
\hline Independent variables & (1) & $(2)$ & (3) \\
\hline \multicolumn{4}{|c|}{ Income quintile (Base $=1^{\text {st }}$ quintile) } \\
\hline $2^{\text {nd }}$. Income quintile & $\begin{array}{c}0.0133 \\
(0.0082)\end{array}$ & $\begin{array}{l}0.0157^{*} \\
(0.0087)\end{array}$ & $\begin{array}{l}0.0197^{* *} \\
(0.0098)\end{array}$ \\
\hline \multirow{2}{*}{$3^{\text {rd }}$ Income quintile } & $0.0384^{* * *}$ & $0.0405^{* * *}$ & $0.0375^{* * *}$ \\
\hline & $(0.0085)$ & $(0.0091)$ & $(0.0102)$ \\
\hline $4^{\text {th }}$ Income quintile & $\begin{array}{c}0.0628^{\star * *} \\
(0.0093)\end{array}$ & $\begin{array}{c}0.0614^{* * *} \\
(0.0098)\end{array}$ & $\begin{array}{l}0.0588^{\star \star \star} \\
(0.0110)\end{array}$ \\
\hline $5^{\text {th }}$ Income quintile & $\begin{array}{l}0.1215^{\star * *} \\
(0.0111)\end{array}$ & $\begin{array}{l}0.1181^{* * *} \\
(0.0115)\end{array}$ & $\begin{array}{l}0.1065^{\star \star \star} \\
(0.0127)\end{array}$ \\
\hline Pseudo $r^{2}$ & 0.1614 & 0.1637 & 0.1683 \\
\hline Observations & 23350 & 21655 & 13708 \\
\hline \multicolumn{4}{|c|}{ Panel B: Marginal effects at base characteristics } \\
\hline \multicolumn{2}{|l|}{ Talking to neighbours } & $\begin{array}{l}-0.0005 \\
(0.0008)\end{array}$ & $\begin{array}{c}0.0003 \\
(0.0005)\end{array}$ \\
\hline \multicolumn{2}{|l|}{ Active in social groups } & $\begin{array}{c}0.0020^{* * *} \\
(0.0007)\end{array}$ & \\
\hline \multicolumn{2}{|l|}{ Trusts most people } & $\begin{array}{l}0.0016^{* * *} \\
(0.0006)\end{array}$ & $\begin{array}{l}0.0008^{* *} \\
(0.0004)\end{array}$ \\
\hline \multicolumn{2}{|l|}{ Religion makes a difference } & $\begin{array}{l}-0.0007 \\
(0.0005)\end{array}$ & $\begin{array}{l}-0.0004 \\
(0.0003)\end{array}$ \\
\hline \multicolumn{4}{|c|}{ No of social groups (Base=None) } \\
\hline \multicolumn{3}{|c|}{ One } & $\begin{array}{l}0.0013^{* *} \\
(0.0006)\end{array}$ \\
\hline \multicolumn{3}{|l|}{ Two } & $\begin{array}{l}0.0025^{\star *} \\
(0.0011)\end{array}$ \\
\hline \multicolumn{2}{|l|}{ Three or more } & & $\begin{array}{l}0.0049^{* *} \\
(0.0021)\end{array}$ \\
\hline \multicolumn{4}{|l|}{ Party identification (Base=None) } \\
\hline Other smaller parties & $\begin{array}{c}0.0009 \\
(0.0006)\end{array}$ & $\begin{array}{c}0.0012 \\
(0.0011)\end{array}$ & $\begin{array}{c}0.0007 \\
(0.0007)\end{array}$ \\
\hline Liberal Democratic & $\begin{array}{l}0.0034^{* * *} \\
(0.0011)\end{array}$ & $\begin{array}{l}0.0044^{* * *} \\
(0.0016)\end{array}$ & $\begin{array}{l}0.0020^{* *} \\
(0.0010)\end{array}$ \\
\hline The Labour Party & $\begin{array}{l}0.0009^{*} \\
(0.0005)\end{array}$ & $\begin{array}{c}0.0012 \\
(0.0008)\end{array}$ & $\begin{array}{c}0.0004 \\
(0.0005)\end{array}$ \\
\hline Conservative Party & $\begin{array}{l}0.0057^{* * *} \\
(0.0016)\end{array}$ & $\begin{array}{c}0.0084^{* * *} \\
(0.0024)\end{array}$ & $\begin{array}{r}0.0045^{* * *} \\
(0.0017)\end{array}$ \\
\hline
\end{tabular}


Table IV. Continued

\begin{tabular}{|c|c|c|c|}
\hline Independent variable & (1) & (2) & (3) \\
\hline \multicolumn{4}{|c|}{ Panel C: Marginal effects at varied characteristics } \\
\hline \multicolumn{2}{|l|}{ Talking to neighbours } & $\begin{array}{l}-0.0108 \\
(0.0156)\end{array}$ & $\begin{array}{c}0.0133 \\
(0.0203)\end{array}$ \\
\hline \multicolumn{2}{|l|}{ Active in social groups } & $\begin{array}{l}0.0528^{* * *} \\
(0.0083)\end{array}$ & \\
\hline \multicolumn{2}{|l|}{ Trusts most people } & $\begin{array}{c}0.0394^{* * *} \\
(0.0086)\end{array}$ & $\begin{array}{c}0.0402^{\star \star \star} \\
(0.0102)\end{array}$ \\
\hline \multicolumn{2}{|l|}{ Religion makes a difference } & $\begin{array}{l}-0.0141^{*} \\
(0.0082)\end{array}$ & $\begin{array}{c}-0.0139 \\
(0.0095)\end{array}$ \\
\hline \multicolumn{4}{|l|}{ No of social groups (Base=None) } \\
\hline \multicolumn{3}{|l|}{ One } & $\begin{array}{c}0.0496^{\star \star \star} \\
(0.0120)\end{array}$ \\
\hline \multicolumn{2}{|l|}{ Two } & & $\begin{array}{c}0.0843^{* * *} \\
(0.0155)\end{array}$ \\
\hline \multicolumn{2}{|l|}{ Three or more } & & $\begin{array}{c}0.1302^{* * *} \\
(0.0187)\end{array}$ \\
\hline \multicolumn{4}{|l|}{ Party identification (Base=None) } \\
\hline Other smaller parties & $\begin{array}{c}0.0326 \\
(0.0203)\end{array}$ & $\begin{array}{c}0.0268 \\
(0.0209)\end{array}$ & $\begin{array}{c}0.0301 \\
(0.0250)\end{array}$ \\
\hline Liberal Democratic & $\begin{array}{c}0.0958^{* * *} \\
(0.0184)\end{array}$ & $\begin{array}{c}0.0771^{* * *} \\
(0.0187)\end{array}$ & $\begin{array}{c}0.0716^{* \star \star} \\
(0.0231)\end{array}$ \\
\hline The Labour Party & $\begin{array}{l}0.0346^{* \star} \\
(0.0161)\end{array}$ & $\begin{array}{c}0.0257 \\
(0.0164)\end{array}$ & $\begin{array}{c}0.0192 \\
(0.0208)\end{array}$ \\
\hline \multirow[t]{2}{*}{ Conservative Party } & $\begin{array}{c}0.1364^{* \star *} \\
(0.0169)\end{array}$ & $\begin{array}{c}0.1222^{* * *} \\
(0.0173)\end{array}$ & $\begin{array}{c}0.1213^{* \star *} \\
(0.0219)\end{array}$ \\
\hline & 23350 & 21655 & 13708 \\
\hline \multicolumn{4}{|c|}{ Panel D: Joint marginal effects at varied characteristics } \\
\hline \multicolumn{2}{|l|}{ Talking to neighbours } & $\begin{array}{c}-0.0078 \\
(0.0114)\end{array}$ & $\begin{array}{c}0.0097 \\
(0.0146)\end{array}$ \\
\hline \multicolumn{2}{|l|}{+ Active in social groups } & $\begin{array}{l}0.0289^{* *} \\
(0.0128)\end{array}$ & \\
\hline \multicolumn{2}{|l|}{+ Three or more social groups } & & $\begin{array}{c}0.1003^{* * \star} \\
(0.0198)\end{array}$ \\
\hline \multicolumn{2}{|l|}{ + Trusts most people } & $\begin{array}{c}0.0570^{* \star *} \\
(0.0138)\end{array}$ & $\begin{array}{c}0.1309^{* * *} \\
(0.0207)\end{array}$ \\
\hline \multirow{2}{*}{\multicolumn{2}{|c|}{$\begin{array}{l}\text { + Identification with the } \\
\text { Conservative Party }\end{array}$}} & $0.1406^{* * *}$ & $0.2173^{* \star \star}$ \\
\hline & & $(0.0171)$ & $(0.0237)$ \\
\hline \multirow{2}{*}{\multicolumn{2}{|c|}{ + Religion makes a difference }} & $\begin{array}{c}0.1299^{* \star *} \\
(0.0187)\end{array}$ & $\begin{array}{c}0.2063^{* * \star} \\
(0.0256)\end{array}$ \\
\hline & & 21655 & 13708 \\
\hline
\end{tabular}


Table $V$. Effects of shift in political party identification

The table presents marginal effects from pooled probit regressions estimates. The dependent variable in all the regressions is the stock market participation dummy variable. The explanatory variables are as defined in Table I. Talking to neighbours equals one if the respondent talks to neighbours every day, once in a week, or once in a month and the value zero if rarely or never. Active in social groups equals one for respondents who are active and zero otherwise. Trusts most people equals one if the response is 'most people can be trusted' and zero otherwise. Religion makes a difference equals one if response is 'some' or 'a great difference' and zero otherwise. Political party shift equals one if the respondent changed party affiliation during the panel period and zero otherwise. Political identification after the shift is a categorical variable equal to one if the respondent has no political affiliation (base level); equals two if respondent is affiliated with other smaller parties; equals three if affiliated with the Liberal Democratic Party; equals four if affiliated with the Labour Party; and equals five if affiliated with the Conservative Party. The interaction term is between political shift and political party identification. The control variables are good neighbourhood dummy; concentrated housing dummy; housing tenure indicators; received windfall income dummy; has no debt dummy; financial capability index; good health dummy; male dummy; age; age squared; cohort; married dummy; has children dummy; education qualification indicators; economic activity indicators; Government office region indicators; and income quintile indicators. Standard errors are clustered at the individual level and are reported in parentheses. The levels of significance are given by * for $10 \%,{ }^{* *}$ for $5 \%$ and ${ }^{* * *}$ for $1 \%$.

\begin{tabular}{lccc}
\hline Independent variable & $(1)$ & $(2)$ & $(3)$ \\
\hline Talking to neighbours & -0.0056 & -0.0081 & -0.0079 \\
& $(0.0112)$ & $(0.0117)$ & $(0.0116)$ \\
Active in social groups & $0.0377^{* * *}$ & $0.0367^{* * *}$ & $0.0363^{* * *}$ \\
& $(0.0053)$ & $(0.0055)$ & $(0.0055)$ \\
Trusts most people & $0.0280^{* * *}$ & $0.0277^{* * *}$ & $0.0277^{* * *}$ \\
& $(0.0057)$ & $(0.0059)$ & $(0.0059)$ \\
Religion makes a difference & $-0.0132^{* *}$ & $-0.0102^{*}$ & $-0.0099^{*}$ \\
& $(0.0057)$ & $(0.0060)$ & $(0.0060)$ \\
Political party shift & -0.0005 & $-0.0116^{*}$ & $-0.0121^{*}$ \\
Party identification (Base=None) & $(0.0064)$ & $(0.0067)$ & $(0.0068)$ \\
Other smaller parties & & & \\
& & 0.0154 & 0.0206 \\
Liberal Democratic & & $(0.0125)$ & $(0.0131)$ \\
The Labour Party & & $0.0486^{* * *}$ & $0.0559^{* * *}$ \\
\multicolumn{1}{c}{ Conservative Party } & & $(0.0117)$ & $(0.0131)$ \\
& & 0.0122 & $0.0180^{*}$ \\
& & $(0.0097)$ & $(0.0106)$ \\
& & $0.0802^{* * *}$ & $0.0847^{* * *}$ \\
& & $(0.0107)$ & $(0.0117)$ \\
\hline
\end{tabular}


Table V. Continued

\begin{tabular}{|c|c|c|c|}
\hline Independent variable & (1) & $(2)$ & (3) \\
\hline \multicolumn{4}{|c|}{ Party identification * political party shift } \\
\hline \multicolumn{2}{|c|}{ Other smaller parties } & & $\begin{array}{l}-0.0054 \\
(0.0173)\end{array}$ \\
\hline \multicolumn{2}{|l|}{ Liberal Democratic } & & $\begin{array}{l}0.0308^{* *} \\
(0.0149)\end{array}$ \\
\hline \multicolumn{2}{|l|}{ The Labour Party } & & $\begin{array}{c}0.0122 \\
(0.0129)\end{array}$ \\
\hline \multicolumn{2}{|l|}{ Conservative Party } & & $\begin{array}{c}0.0569^{* * *} \\
(0.0141)\end{array}$ \\
\hline Good neighbourhood & $\begin{array}{l}0.0186^{* *} \\
(0.0090)\end{array}$ & $\begin{array}{c}0.0107 \\
(0.0096)\end{array}$ & $\begin{array}{c}0.0107 \\
(0.0096)\end{array}$ \\
\hline Concentrated housing & $\begin{array}{l}-0.0031 \\
(0.0096)\end{array}$ & $\begin{array}{c}0.0009 \\
(0.0100)\end{array}$ & $\begin{array}{c}0.0009 \\
(0.0100)\end{array}$ \\
\hline \multicolumn{4}{|l|}{ Housing Tenure (Base=rented) } \\
\hline Mortgaged & $\begin{array}{c}0.0947^{* * *} \\
(0.0074)\end{array}$ & $\begin{array}{c}0.0881^{* * *} \\
(0.0078)\end{array}$ & $\begin{array}{c}0.0882^{* * *} \\
(0.0078)\end{array}$ \\
\hline Outright owner & $\begin{array}{c}0.1670^{* * *} \\
(0.0086)\end{array}$ & $\begin{array}{c}0.1560^{* * *} \\
(0.0090)\end{array}$ & $\begin{array}{c}0.1557^{* * *} \\
(0.0090)\end{array}$ \\
\hline Received windfall income & $\begin{array}{c}0.0382^{* * *} \\
(0.0061)\end{array}$ & $\begin{array}{c}0.0347^{* * *} \\
(0.0063)\end{array}$ & $\begin{array}{c}0.0346^{* * *} \\
(0.0063)\end{array}$ \\
\hline Has no debt & $\begin{array}{l}0.0345^{* * *} \\
(0.0058)\end{array}$ & $\begin{array}{l}0.0335^{* * *} \\
(0.0061)\end{array}$ & $\begin{array}{c}0.0334^{* * *} \\
(0.0061)\end{array}$ \\
\hline Financial capability index & $\begin{array}{c}0.0977^{* * *} \\
(0.0090)\end{array}$ & $\begin{array}{c}0.0922^{* * *} \\
(0.0093)\end{array}$ & $\begin{array}{c}0.0923^{* * *} \\
(0.0093)\end{array}$ \\
\hline Computer user & $\begin{array}{c}0.0343^{* * *} \\
(0.0064)\end{array}$ & $\begin{array}{c}0.0352^{* * *} \\
(0.0066)\end{array}$ & $\begin{array}{c}0.0349^{* * *} \\
(0.0066)\end{array}$ \\
\hline Good health & $\begin{array}{l}0.0150^{* *} \\
(0.0061)\end{array}$ & $\begin{array}{l}0.0144^{* *} \\
(0.0064)\end{array}$ & $\begin{array}{l}0.0145^{* *} \\
(0.0064)\end{array}$ \\
\hline Male & $\begin{array}{c}0.0221^{* * *} \\
(0.0065)\end{array}$ & $\begin{array}{c}0.0277^{* * *} \\
(0.0067)\end{array}$ & $\begin{array}{c}0.0279 * * * \\
(0.0067)\end{array}$ \\
\hline Age & $\begin{array}{c}0.0037^{* * *} \\
(0.0014)\end{array}$ & $\begin{array}{c}0.0043^{* * *} \\
(0.0015)\end{array}$ & $\begin{array}{c}0.0043^{* * *} \\
(0.0015)\end{array}$ \\
\hline Age square & $\begin{array}{c}-0.0001^{* * *} \\
(0.0000)\end{array}$ & $\begin{array}{c}-0.0001^{* * *} \\
(0.0000)\end{array}$ & $\begin{array}{c}-0.0001^{* * *} \\
(0.0000)\end{array}$ \\
\hline cohort & $\begin{array}{c}-0.0090^{* * *} \\
(0.0007)\end{array}$ & $\begin{array}{c}-0.0084^{\star * *} \\
(0.0007)\end{array}$ & $\begin{array}{c}-0.0083^{* * *} \\
(0.0007)\end{array}$ \\
\hline Married & $\begin{array}{l}0.0118^{*} \\
(0.0067)\end{array}$ & $\begin{array}{c}0.0110 \\
(0.0069)\end{array}$ & $\begin{array}{c}0.0111 \\
(0.0069)\end{array}$ \\
\hline Has child(ren) & $\begin{array}{c}-0.0240^{* * *} \\
(0.0070)\end{array}$ & $\begin{array}{c}-0.0217^{\star \star *} \\
(0.0073)\end{array}$ & $\begin{array}{c}-0.0215^{\star * *} \\
(0.0073)\end{array}$ \\
\hline \multicolumn{4}{|c|}{ Education qualification (Base $=$ None) } \\
\hline Lower level & $\begin{array}{c}0.0500^{* * *} \\
(0.0108)\end{array}$ & $\begin{array}{c}0.0514^{* * *} \\
(0.0112)\end{array}$ & $\begin{array}{c}0.0513^{* * *} \\
(0.0112)\end{array}$ \\
\hline GCE level & $\begin{array}{c}0.0988^{* * *} \\
(0.0083)\end{array}$ & $\begin{array}{l}0.0933^{* * *} \\
(0.0087)\end{array}$ & $\begin{array}{c}0.0931^{* * *} \\
(0.0087)\end{array}$ \\
\hline Other higher & $\begin{array}{c}0.1085^{* \star *} \\
(0.0086)\end{array}$ & $\begin{array}{c}0.1084^{* \star \star} \\
(0.0091)\end{array}$ & $\begin{array}{l}0.1080^{* \star \star} \\
(0.0091)\end{array}$ \\
\hline
\end{tabular}


Table V. Continued

\begin{tabular}{|c|c|c|c|}
\hline Independent variable & (1) & (2) & (3) \\
\hline $\begin{array}{l}\text { First degree and } \\
\text { above }\end{array}$ & $(0.0118)$ & $\begin{array}{c}0.1525^{\star * *} \\
(0.0123)\end{array}$ & $0.1520^{* * *}$ \\
\hline \multicolumn{4}{|c|}{ Economic Activity (Base=Unemployed) } \\
\hline Retired & $\begin{array}{c}0.0589^{* * *} \\
(0.0126)\end{array}$ & $\begin{array}{c}0.0580^{* * *} \\
(0.0129)\end{array}$ & $\begin{array}{c}0.0580^{* * *} \\
(0.0129)\end{array}$ \\
\hline Self employed & $\begin{array}{c}0.0071 \\
(0.0124)\end{array}$ & $\begin{array}{c}0.0012 \\
(0.0128)\end{array}$ & $\begin{array}{c}0.0006 \\
(0.0128)\end{array}$ \\
\hline Employed & $\begin{array}{l}-0.0023 \\
(0.0091)\end{array}$ & $\begin{array}{l}-0.0040 \\
(0.0095)\end{array}$ & $\begin{array}{l}-0.0041 \\
(0.0095)\end{array}$ \\
\hline \multicolumn{4}{|l|}{ Region (Base=North East) } \\
\hline North West & $\begin{array}{c}0.0489^{* * *} \\
(0.0184)\end{array}$ & $\begin{array}{l}0.0421^{* *} \\
(0.0194)\end{array}$ & $\begin{array}{l}0.0420^{* *} \\
(0.0194)\end{array}$ \\
\hline Yorkshire \& Humber & $\begin{array}{c}0.0524^{* * *} \\
(0.0192)\end{array}$ & $\begin{array}{l}0.0542^{* * *} \\
(0.0204)\end{array}$ & $\begin{array}{r}0.0545^{* * *} \\
(0.0203)\end{array}$ \\
\hline East Midlands & $\begin{array}{c}0.0523^{* * *} \\
(0.0199)\end{array}$ & $\begin{array}{l}0.0401^{*} \\
(0.0206)\end{array}$ & $\begin{array}{l}0.0399^{*} \\
(0.0206)\end{array}$ \\
\hline West Midlands & $\begin{array}{c}0.0302 \\
(0.0189)\end{array}$ & $\begin{array}{c}0.0219 \\
(0.0199)\end{array}$ & $\begin{array}{c}0.0218 \\
(0.0199)\end{array}$ \\
\hline East of England & $\begin{array}{c}0.1157^{* \star *} \\
(0.0198)\end{array}$ & $\begin{array}{c}0.1007^{* * *} \\
(0.0207)\end{array}$ & $\begin{array}{c}0.0999^{* * *} \\
(0.0207)\end{array}$ \\
\hline London & $\begin{array}{c}0.1051^{* * *} \\
(0.0202)\end{array}$ & $\begin{array}{c}0.0905^{\star \star \star} \\
(0.0209)\end{array}$ & $\begin{array}{l}0.0905^{* * *} \\
(0.0209)\end{array}$ \\
\hline South East & $\begin{array}{c}0.0764^{* * *} \\
(0.0181)\end{array}$ & $\begin{array}{l}0.0641^{* * *} \\
(0.0191)\end{array}$ & $\begin{array}{r}0.0637^{* * *} \\
(0.0191)\end{array}$ \\
\hline South West & $\begin{array}{l}0.0491^{* *} \\
(0.0194)\end{array}$ & $\begin{array}{l}0.0338^{*} \\
(0.0203)\end{array}$ & $\begin{array}{l}0.0336^{*} \\
(0.0203)\end{array}$ \\
\hline Wales & $\begin{array}{l}0.0361^{* *} \\
(0.0172)\end{array}$ & $\begin{array}{l}0.0398^{* *} \\
(0.0182)\end{array}$ & $\begin{array}{l}0.0401^{* *} \\
(0.0182)\end{array}$ \\
\hline Scotland & $\begin{array}{c}0.0555^{\star * *} \\
(0.0173)\end{array}$ & $\begin{array}{c}0.0612^{* * *} \\
(0.0185)\end{array}$ & $\begin{array}{c}0.0610^{* * *} \\
(0.0185)\end{array}$ \\
\hline Northern Ireland & $\begin{array}{l}-0.0438^{* *} \\
(0.0178)\end{array}$ & $\begin{array}{l}-0.0309 \\
(0.0204)\end{array}$ & $\begin{array}{l}-0.0329 \\
(0.0215)\end{array}$ \\
\hline Income quintile (Base $=1^{\text {st }}$ quir & & & \\
\hline $2^{\text {nd }}$. Income quintile & $\begin{array}{l}0.0166^{* *} \\
(0.0082)\end{array}$ & $\begin{array}{l}0.0159^{*} \\
(0.0087)\end{array}$ & $\begin{array}{l}0.0159^{*} \\
(0.0087)\end{array}$ \\
\hline $3^{\text {rd }}$ Income quintile & $\begin{array}{c}0.0422^{* \star *} \\
(0.0086)\end{array}$ & $\begin{array}{c}0.0404^{\star * *} \\
(0.0091)\end{array}$ & $\begin{array}{l}0.0404^{* * *} \\
(0.0091)\end{array}$ \\
\hline $4^{\text {th }}$ Income quintile & $\begin{array}{c}0.0677^{* * *} \\
(0.0095)\end{array}$ & $\begin{array}{c}0.0614^{* * *} \\
(0.0098)\end{array}$ & $\begin{array}{c}0.0613^{* * *} \\
(0.0098)\end{array}$ \\
\hline $5^{\text {th }}$ Income quintile & $\begin{array}{c}0.1243^{* * *} \\
(0.0110)\end{array}$ & $\begin{array}{l}0.1181^{* * *} \\
(0.0115)\end{array}$ & $\begin{array}{r}0.1177^{* * *} \\
(0.0115)\end{array}$ \\
\hline Pseudo $r^{2}$ & 0.1576 & 0.1638 & 0.1642 \\
\hline Observations & 23916 & 21655 & 21655 \\
\hline
\end{tabular}


Table VI. Marginal effects with lagged and alternative dependent variables

The table presents marginal effects from pooled probit regressions (column (1), (2), and (3)) and a pooled poisson regression in column (4). The dependent variables are stock market participation dummy (SMP1) (Column 1); dummy for the broadened definition of stock market participation (SMP2) (column 2); dummy for investment in fixed interest asset (FIA) (column 3); and number of investment products (NIP) (column 4). The samples consist of individuals in the British Household Panel Survey (BHPS) for the 1995, 2000 and 2005 waves. The explanatory variables are as defined in Table I. Talking to neighbours equals one if the respondent talks to neighbours every day, once in a week, or once in a month and the value zero if rarely or never. Active in social groups equals one for respondents who are active and zero otherwise. Trusts most people equals one if the response is 'most people can be trusted' and zero otherwise. Religion makes a difference equals one if response is 'some' or 'a great difference' and zero otherwise. Political identification is a categorical variable equal to one if the respondent has no political affiliation (base level); equals two if the respondent is affiliated with other smaller parties; equals three if affiliated with the Liberal Democratic Party; equals four if affiliated with the Labour Party; and equals five if affiliated with the Conservative Party. The control variables are good neighbourhood dummy; concentrated housing dummy; housing tenure indicators; received windfall income dummy; has no debt dummy; financial capability index; good health dummy; male dummy; age; age squared; cohort; married dummy; has children dummy; education qualification indicators; economic activity indicators; Government office region indicators; and income quintile indicators. Standard errors are clustered at the individual level and are reported in parentheses. The levels of significance are given by ${ }^{*}$ for $10 \%,{ }^{* *}$ for $5 \%$ and ${ }^{* * \star}$ for $1 \%$.

\begin{tabular}{|c|c|c|c|c|}
\hline Independent variable & $\begin{array}{l}\text { SMP1 } \\
(1)\end{array}$ & $\begin{array}{l}\text { SMP2 } \\
\text { (2) }\end{array}$ & $\begin{array}{l}\text { FIA } \\
(3)\end{array}$ & $\begin{array}{l}\text { NIP } \\
(4)\end{array}$ \\
\hline Stock market participation lagged & $\begin{array}{c}0.3489^{* * *} \\
(0.0114)\end{array}$ & & & \\
\hline Talking to neighbours & $\begin{array}{c}0.0101 \\
(0.0137)\end{array}$ & $\begin{array}{l}-0.0055 \\
(0.0131)\end{array}$ & $\begin{array}{c}0.0001 \\
(0.0132)\end{array}$ & $\begin{array}{l}-0.0043 \\
(0.0266)\end{array}$ \\
\hline Active in social groups & $\begin{array}{c}0.0275^{\star * *} \\
(0.0068)\end{array}$ & $\begin{array}{c}0.0447^{\star * *} \\
(0.0062)\end{array}$ & $\begin{array}{c}0.0268^{\star * *} \\
(0.0065)\end{array}$ & $\begin{array}{c}0.0817^{* * *} \\
(0.0122)\end{array}$ \\
\hline Trusts most people & $\begin{array}{c}0.0212^{* * *} \\
(0.0072)\end{array}$ & $\begin{array}{c}0.0284^{* * *} \\
(0.0066)\end{array}$ & $\begin{array}{l}0.0169^{\star *} \\
(0.0068)\end{array}$ & $\begin{array}{c}0.0554^{\star \star *} \\
(0.0134)\end{array}$ \\
\hline Religion makes a difference & $\begin{array}{l}-0.0048 \\
(0.0068)\end{array}$ & $\begin{array}{c}-0.0160^{* *} \\
(0.0063)\end{array}$ & $\begin{array}{c}-0.0197^{* * *} \\
(0.0065)\end{array}$ & $\begin{array}{c}-0.0328^{* * *} \\
(0.0127)\end{array}$ \\
\hline Party identification (Base=None) & 0.0000 & 0.0000 & 0.0000 & 0.0000 \\
\hline Other smaller parties & $\begin{array}{c}0.0095 \\
(0.0165)\end{array}$ & $\begin{array}{l}0.0264^{*} \\
(0.0138)\end{array}$ & $\begin{array}{c}0.0206 \\
(0.0138)\end{array}$ & $\begin{array}{c}0.0338 \\
(0.0298)\end{array}$ \\
\hline Liberal Democratic & $\begin{array}{c}0.0408^{* * *} \\
(0.0134)\end{array}$ & $\begin{array}{c}0.0661^{* * *} \\
(0.0131)\end{array}$ & $\begin{array}{l}0.0336^{* *} \\
(0.0131)\end{array}$ & $\begin{array}{c}0.1084^{* \star \star} \\
(0.0268)\end{array}$ \\
\hline The Labour Party & $\begin{array}{c}0.0151 \\
(0.0115)\end{array}$ & $\begin{array}{l}0.0235^{* *} \\
(0.0107)\end{array}$ & $\begin{array}{c}-0.0233^{* *} \\
(0.0108)\end{array}$ & $\begin{array}{c}0.0308 \\
(0.0226)\end{array}$ \\
\hline Conservative Party & $\begin{array}{c}0.0634^{* * *} \\
(0.0122)\end{array}$ & $\begin{array}{c}0.0995^{\star * *} \\
(0.0119)\end{array}$ & $\begin{array}{c}0.0581^{* * *} \\
(0.0119)\end{array}$ & $\begin{array}{c}0.1733^{\star \star \star \star} \\
(0.0246)\end{array}$ \\
\hline
\end{tabular}


Table VI. Continued

\begin{tabular}{|c|c|c|c|c|}
\hline Independent variable & $\begin{array}{c}\text { SMP1 } \\
(1)\end{array}$ & $\begin{array}{c}\text { SMP2 } \\
(2)\end{array}$ & $\begin{array}{l}\text { FIA } \\
(3)\end{array}$ & $\begin{array}{c}\text { NIP } \\
(4) \\
\end{array}$ \\
\hline Good neighbourhood & $\begin{array}{c}-0.0080 \\
(0.0124)\end{array}$ & $\begin{array}{c}0.0306^{* * *} \\
(0.0104)\end{array}$ & $\begin{array}{c}0.0334^{* * *} \\
(0.0102)\end{array}$ & $\begin{array}{c}0.0366 \\
(0.0231)\end{array}$ \\
\hline Concentrated housing & $\begin{array}{c}0.0103 \\
(0.0120)\end{array}$ & $\begin{array}{l}-0.0066 \\
(0.0110)\end{array}$ & $\begin{array}{l}0.0195^{\star} \\
(0.0103)\end{array}$ & $\begin{array}{c}0.0026 \\
(0.0257)\end{array}$ \\
\hline \multicolumn{5}{|l|}{ Housing Tenure (Base=rented) } \\
\hline Mortgaged & $\begin{array}{c}0.0761^{\star * *} \\
(0.0104)\end{array}$ & $\begin{array}{c}0.1172^{* * *} \\
(0.0097)\end{array}$ & $\begin{array}{c}0.0620^{* * *} \\
(0.0099)\end{array}$ & $\begin{array}{c}0.2144^{* * *} \\
(0.0173)\end{array}$ \\
\hline Outright owner & $\begin{array}{c}0.1236^{* * *} \\
(0.0117)\end{array}$ & $\begin{array}{c}0.2260^{* * *} \\
(0.0106)\end{array}$ & $\begin{array}{c}0.1188^{* * *} \\
(0.0106)\end{array}$ & $\begin{array}{c}0.3400^{* * *} \\
(0.0204)\end{array}$ \\
\hline Received windfall income & $\begin{array}{l}0.0176 * * \\
(0.0081)\end{array}$ & $\begin{array}{c}0.0502^{* * *} \\
(0.0072)\end{array}$ & $\begin{array}{c}0.0754^{\star * *} \\
(0.0072)\end{array}$ & $\begin{array}{c}0.0726 * * * \\
(0.0129)\end{array}$ \\
\hline Has no debt & $\begin{array}{l}0.0154^{\star *} \\
(0.0076)\end{array}$ & $\begin{array}{c}0.0517^{\star * *} \\
(0.0069)\end{array}$ & $\begin{array}{l}-0.0003 \\
(0.0070)\end{array}$ & $\begin{array}{c}0.0744^{* * *} \\
(0.0136)\end{array}$ \\
\hline Financial capability index & $\begin{array}{c}0.0760^{* * *} \\
(0.0118)\end{array}$ & $\begin{array}{c}0.1386^{\star \star *} \\
(0.0101)\end{array}$ & $\begin{array}{c}0.1264^{\star \star \star} \\
(0.0075)\end{array}$ & $\begin{array}{c}0.2538^{* * *} \\
(0.0237)\end{array}$ \\
\hline Computer user & $\begin{array}{l}0.0209^{* *} \\
(0.0084)\end{array}$ & $\begin{array}{c}0.0363^{\star \star \star} \\
(0.0075)\end{array}$ & $\begin{array}{c}0.0262^{\star \star \star} \\
(0.0076)\end{array}$ & $\begin{array}{c}0.0624^{\star \star \star} \\
(0.0147)\end{array}$ \\
\hline Good health & $\begin{array}{c}0.0009 \\
(0.0080)\end{array}$ & $\begin{array}{c}0.0321^{* * *} \\
(0.0071)\end{array}$ & $\begin{array}{c}0.0224^{* * *} \\
(0.0072)\end{array}$ & $\begin{array}{c}0.0237 \\
(0.0147)\end{array}$ \\
\hline Male & $\begin{array}{l}0.0136^{\star} \\
(0.0076)\end{array}$ & $\begin{array}{l}-0.0107 \\
(0.0073)\end{array}$ & $\begin{array}{c}-0.0476^{* * *} \\
(0.0072)\end{array}$ & $\begin{array}{c}0.0528^{* \star *} \\
(0.0162)\end{array}$ \\
\hline Age & $\begin{array}{c}-0.0158^{* * *} \\
(0.0022)\end{array}$ & $\begin{array}{c}0.0277^{* * *} \\
(0.0016)\end{array}$ & $\begin{array}{c}0.0260^{* * *} \\
(0.0016)\end{array}$ & $\begin{array}{c}0.0182^{* * *} \\
(0.0036)\end{array}$ \\
\hline Age square & $\begin{array}{c}-0.0001^{* * *} \\
(0.0000)\end{array}$ & $\begin{array}{c}-0.0001^{* * *} \\
(0.0000)\end{array}$ & $\begin{array}{c}-0.0000 \\
(0.0000)\end{array}$ & $\begin{array}{c}-0.0003^{* * *} \\
(0.0000)\end{array}$ \\
\hline cohort & $\begin{array}{c}-0.0242^{* * *} \\
(0.0014)\end{array}$ & $\begin{array}{c}0.0115^{\star * *} \\
(0.0008)\end{array}$ & $\begin{array}{c}0.0225^{\star * *} \\
(0.0009)\end{array}$ & $\begin{array}{c}-0.0148^{* * *} \\
(0.0013)\end{array}$ \\
\hline Married & $\begin{array}{l}-0.0113 \\
(0.0082)\end{array}$ & $\begin{array}{c}0.0333^{* * *} \\
(0.0076)\end{array}$ & $\begin{array}{c}0.0262^{* * *} \\
(0.0077)\end{array}$ & $\begin{array}{c}0.0104 \\
(0.0167)\end{array}$ \\
\hline Has child(ren) & $\begin{array}{c}0.0060 \\
(0.0090)\end{array}$ & $\begin{array}{c}-0.0674^{* * *} \\
(0.0081)\end{array}$ & $\begin{array}{c}-0.0197^{\star *} \\
(0.0081)\end{array}$ & $\begin{array}{c}-0.0174 \\
(0.0175)\end{array}$ \\
\hline Education qualification (Base $=\mathrm{Nc}$ & & & & \\
\hline Lower level & $\begin{array}{l}0.0319^{* *} \\
(0.0140)\end{array}$ & $\begin{array}{c}0.0733^{* * *} \\
(0.0129)\end{array}$ & $\begin{array}{c}0.0578^{\star * *} \\
(0.0131)\end{array}$ & $\begin{array}{c}0.1007^{* * *} \\
(0.0276)\end{array}$ \\
\hline GCE level & $\begin{array}{c}0.0735^{* * *} \\
(0.0108)\end{array}$ & $\begin{array}{c}0.1296^{* * *} \\
(0.0102)\end{array}$ & $\begin{array}{c}0.0987^{* * *} \\
(0.0105)\end{array}$ & $\begin{array}{c}0.1976^{* * *} \\
(0.0203)\end{array}$ \\
\hline Other higher & $\begin{array}{c}0.0732^{\star * *} \\
(0.0107)\end{array}$ & $\begin{array}{c}0.1463^{\star * *} \\
(0.0105)\end{array}$ & $\begin{array}{c}0.1186^{\star * *} \\
(0.0107)\end{array}$ & $\begin{array}{c}0.2398^{* * *} \\
(0.0211)\end{array}$ \\
\hline First degree and above & $\begin{array}{c}0.0923^{* * *} \\
(0.0135)\end{array}$ & $\begin{array}{c}0.2262^{* * *} \\
(0.0137)\end{array}$ & $\begin{array}{c}0.1674^{* * *} \\
(0.0134)\end{array}$ & $\begin{array}{c}0.3193^{* * *} \\
(0.0281)\end{array}$ \\
\hline
\end{tabular}


Table VI. Continued

\begin{tabular}{|c|c|c|c|c|}
\hline Independent variable & $\begin{array}{l}\text { SMP1 } \\
(1)\end{array}$ & $\begin{array}{l}\text { SMP2 } \\
(2)\end{array}$ & $\begin{array}{l}\text { FIA } \\
(3)\end{array}$ & $\begin{array}{l}\text { NIP } \\
(4)\end{array}$ \\
\hline \multicolumn{5}{|l|}{$\begin{array}{l}\text { Economic Activity } \\
\text { (Base=Unemployed) }\end{array}$} \\
\hline Retired & $\begin{array}{l}0.0317^{*} \\
(0.0164)\end{array}$ & $\begin{array}{c}0.0888^{* * *} \\
(0.0136)\end{array}$ & $\begin{array}{c}0.0714^{* * *} \\
(0.0138)\end{array}$ & $\begin{array}{c}0.1142^{* \star \star} \\
(0.0312)\end{array}$ \\
\hline Self employed & $\begin{array}{c}0.0122 \\
(0.0163)\end{array}$ & $\begin{array}{l}0.0421^{* * *} \\
(0.0145)\end{array}$ & $\begin{array}{c}0.0201 \\
(0.0150)\end{array}$ & $\begin{array}{l}-0.0175 \\
(0.0296)\end{array}$ \\
\hline Employed & $\begin{array}{l}-0.0055 \\
(0.0124)\end{array}$ & $\begin{array}{l}0.0203^{*} \\
(0.0106)\end{array}$ & $\begin{array}{l}0.0326^{* * *} \\
(0.0105)\end{array}$ & $\begin{array}{c}-0.0319 \\
(0.0242)\end{array}$ \\
\hline \multicolumn{5}{|l|}{ Region (Base=North East) } \\
\hline North West & $\begin{array}{c}0.0105 \\
(0.0188)\end{array}$ & $\begin{array}{l}0.0501^{* *} \\
(0.0217)\end{array}$ & $\begin{array}{c}0.0292 \\
(0.0199)\end{array}$ & $\begin{array}{l}0.1061^{\star *} \\
(0.0517)\end{array}$ \\
\hline Yorkshire \& Humber & $\begin{array}{l}0.0403^{* *} \\
(0.0196)\end{array}$ & $\begin{array}{l}0.0593^{* * *} \\
(0.0222)\end{array}$ & $\begin{array}{l}0.0419^{* *} \\
(0.0205)\end{array}$ & $\begin{array}{l}0.1191^{* *} \\
(0.0548)\end{array}$ \\
\hline East Midlands & $\begin{array}{c}0.0194 \\
(0.0196)\end{array}$ & $\begin{array}{c}0.0232 \\
(0.0227)\end{array}$ & $\begin{array}{c}0.0280 \\
(0.0210)\end{array}$ & $\begin{array}{l}0.1158^{* \star} \\
(0.0543)\end{array}$ \\
\hline West Midlands & $\begin{array}{c}0.0090 \\
(0.0192)\end{array}$ & $\begin{array}{l}0.0195 \\
(0.0227)\end{array}$ & $\begin{array}{l}0.0339 \\
(0.0209)\end{array}$ & $\begin{array}{c}0.0512 \\
(0.0526)\end{array}$ \\
\hline East of England & $\begin{array}{l}0.0480^{* *} \\
(0.0192)\end{array}$ & $\begin{array}{l}0.0770^{* * *} \\
(0.0230)\end{array}$ & $\begin{array}{l}0.0381^{*} \\
(0.0210)\end{array}$ & $\begin{array}{l}0.2423^{* \star \star} \\
(0.0538)\end{array}$ \\
\hline London & $\begin{array}{c}0.0667^{* \star *} \\
(0.0206)\end{array}$ & $\begin{array}{l}0.0545^{\star *} \\
(0.0226)\end{array}$ & $\begin{array}{l}0.0556^{* * *} \\
(0.0207)\end{array}$ & $\begin{array}{l}0.2341^{* * \star} \\
(0.0553)\end{array}$ \\
\hline South East & $\begin{array}{l}0.0394^{* *} \\
(0.0183)\end{array}$ & $\begin{array}{c}0.0624^{* * *} \\
(0.0212)\end{array}$ & $\begin{array}{c}0.0526^{* * *} \\
(0.0194)\end{array}$ & $\begin{array}{l}0.1465^{* \star \star} \\
(0.0499)\end{array}$ \\
\hline South West & $\begin{array}{c}0.0297 \\
(0.0194)\end{array}$ & $\begin{array}{l}0.0500^{* *} \\
(0.0224)\end{array}$ & $\begin{array}{l}0.0562^{* * *} \\
(0.0208)\end{array}$ & $\begin{array}{l}0.1043^{*} \\
(0.0537)\end{array}$ \\
\hline Wales & $\begin{array}{c}0.0142 \\
(0.0183)\end{array}$ & $\begin{array}{l}0.0490^{* *} \\
(0.0203)\end{array}$ & $\begin{array}{c}0.0135 \\
(0.0187)\end{array}$ & $\begin{array}{c}0.0141 \\
(0.0470)\end{array}$ \\
\hline Scotland & $\begin{array}{c}0.0292 \\
(0.0183)\end{array}$ & $\begin{array}{l}0.0537^{* * *} \\
(0.0204)\end{array}$ & $\begin{array}{l}0.0392^{* *} \\
(0.0186)\end{array}$ & $\begin{array}{c}0.0600 \\
(0.0480)\end{array}$ \\
\hline Northern Ireland & & $\begin{array}{l}-0.0955^{* * *} \\
(0.0225)\end{array}$ & $\begin{array}{l}-0.2029^{* * *} \\
(0.0223)\end{array}$ & $\begin{array}{r}-0.1808^{* *+} \\
(0.0465)\end{array}$ \\
\hline \multicolumn{5}{|l|}{ Income quintile (Base $=1^{\text {st }}$} \\
\hline $2^{\text {nd }}$. Income quintile & $\begin{array}{l}-0.0016 \\
(0.0123)\end{array}$ & $\begin{array}{c}0.0284^{* * *} \\
(0.0102)\end{array}$ & $\begin{array}{l}0.0190^{*} \\
(0.0105)\end{array}$ & $\begin{array}{c}0.0261 \\
(0.0186)\end{array}$ \\
\hline $3^{\text {rd }}$ Income quintile & $\begin{array}{c}0.0126 \\
(0.0122)\end{array}$ & $\begin{array}{c}0.0597^{* * *} \\
(0.0107)\end{array}$ & $\begin{array}{c}0.0427^{* * *} \\
(0.0109)\end{array}$ & $\begin{array}{c}0.0928^{\star * \star} \\
(0.0198)\end{array}$ \\
\hline $4^{\text {th }}$ Income quintile & $\begin{array}{l}0.0267^{* *} \\
(0.0127)\end{array}$ & $\begin{array}{c}0.0963^{* * *} \\
(0.0115)\end{array}$ & $\begin{array}{c}0.0594^{* * *} \\
(0.0118)\end{array}$ & $\begin{array}{c}0.1288^{* \star \star} \\
(0.0212)\end{array}$ \\
\hline $5^{\text {th }}$ Income quintile & $\begin{array}{c}0.0700^{* * *} \\
(0.0140)\end{array}$ & $\begin{array}{c}0.1562^{* * *} \\
(0.0130)\end{array}$ & $\begin{array}{c}0.0855^{* * *} \\
(0.0129)\end{array}$ & $\begin{array}{c}0.2335^{\star \star \star} \\
(0.0254)\end{array}$ \\
\hline $\begin{array}{l}\text { Pseudo } r^{2} \\
\text { Observations }\end{array}$ & $\begin{array}{l}0.2665 \\
11111\end{array}$ & $\begin{array}{l}0.2017 \\
21655\end{array}$ & $\begin{array}{l}0.1358 \\
21655\end{array}$ & $\begin{array}{l}0.1723 \\
21655\end{array}$ \\
\hline
\end{tabular}




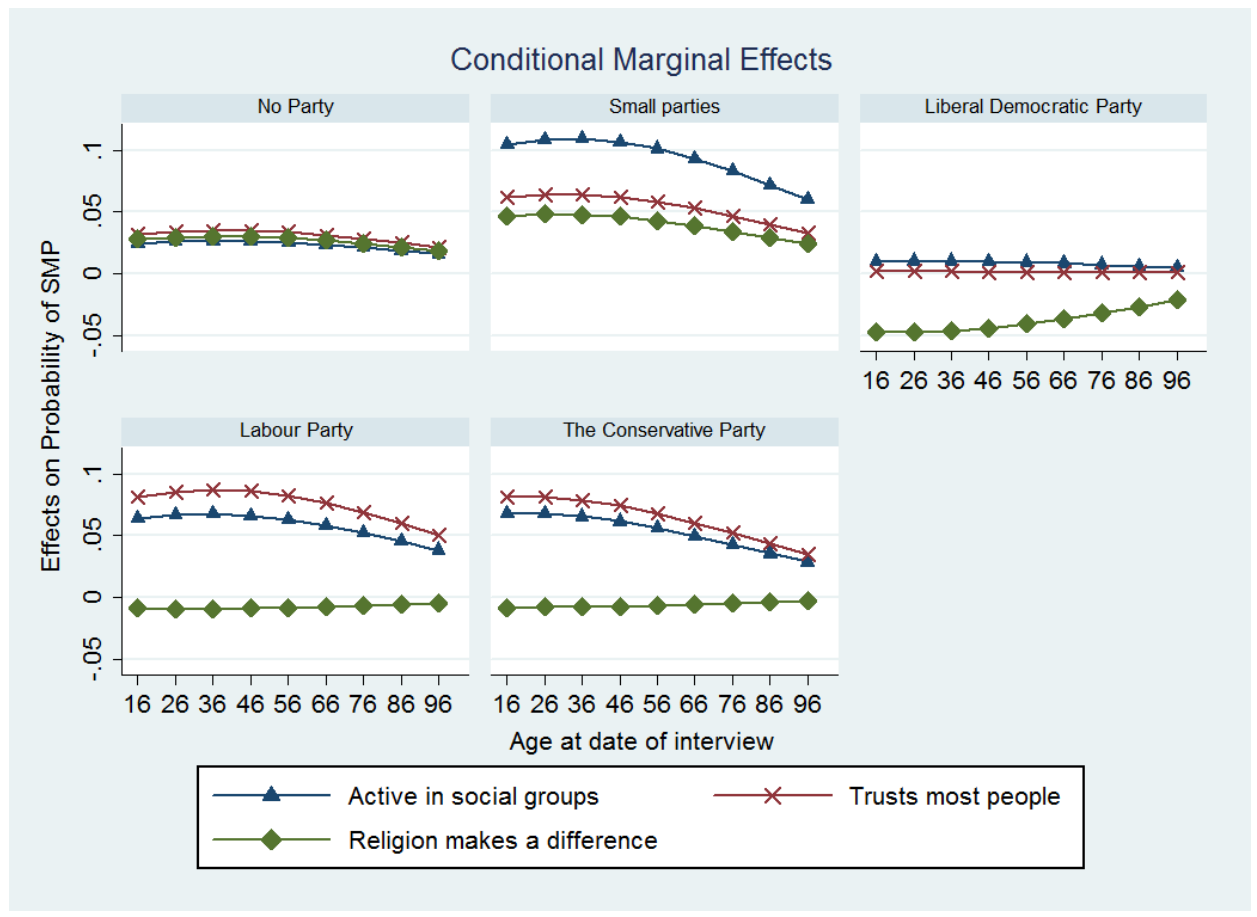

Figure 1. Conditional marginal effects with social engagement interaction terms

The figure displays the conditional marginal effects derived from a pooled probit regression using the specifications in Table IV, Column 2 and interaction terms for the variables active in social groups, trusts most people, and religion makes a difference. The marginal effects are calculated using varied characteristics as defined in the legend to Table III. Other variables are evaluated at their average values: age square, cohort and financial capability. The plotted marginal effects for the variable active in social group are significant at the 5\% level for identification with the Labour Party and at the $10 \%$ level for identification with the Conservative Party and Small Parties, among individuals aged below the age of 86 . For the variable trusts most people, the plotted marginal effects are significant at the $1 \%$ level for identification with the Labour Party and at the $5 \%$ level for identification with the Conservative party, among respondents aged 76 and below, and at $5 \%$ and $10 \%$ respectively among respondents above age 76 . Religion is not significant. 


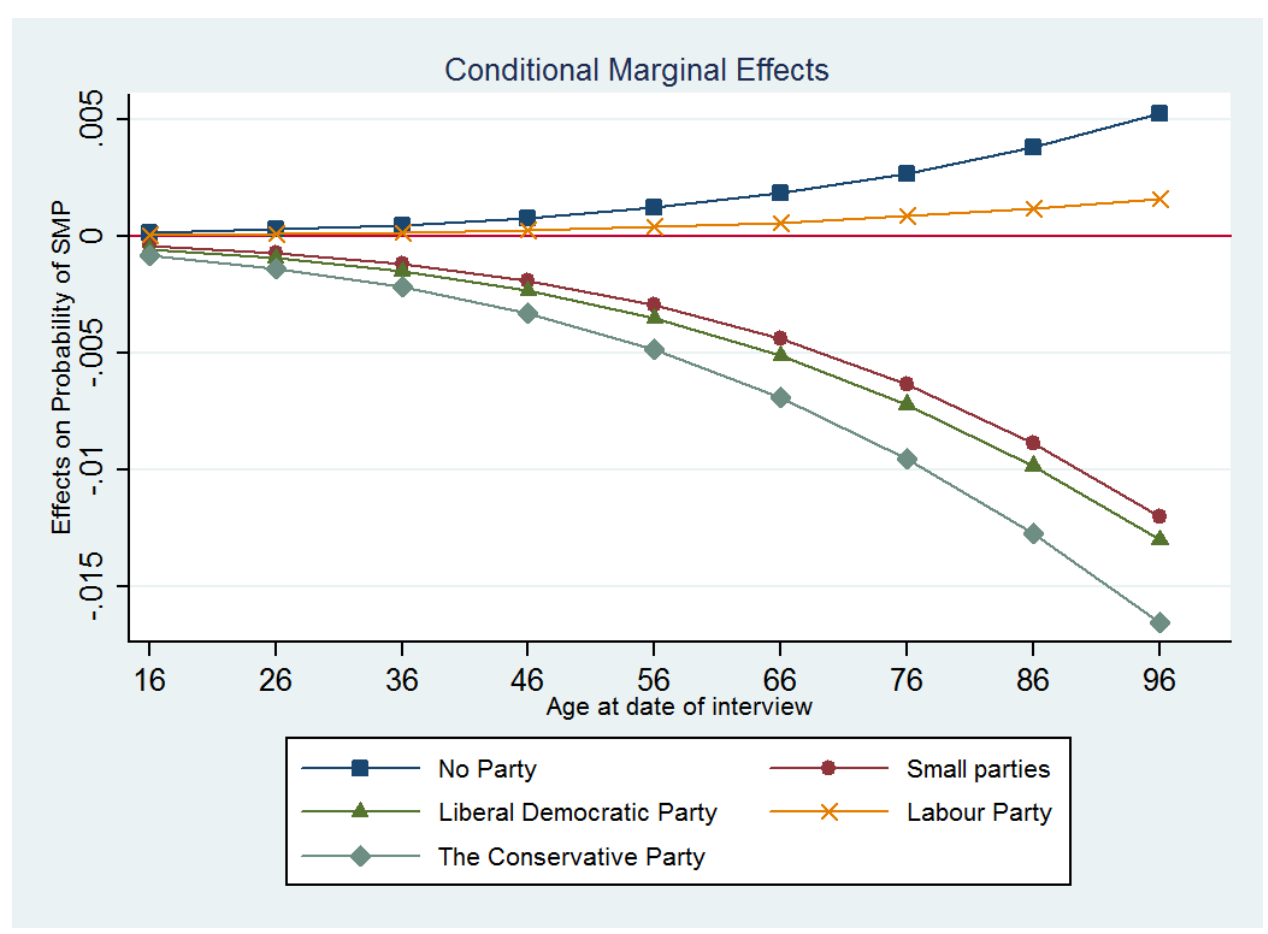

Figure 2. Conditional marginal effects of shift in political preferences - base characteristics

The figure displays the conditional marginal effects derived from a pooled probit regression using the specifications in Table IV, Column 4 and an interaction term between the variables political party shift and political party identification after the shift. The marginal effects are evaluated at base characteristics (see Table III legend) for each variable, apart from age square, cohort, and financial capability that take average values. The marginal effects are significant at the $10 \%$ level for identification with the Conservative Party among individuals aged between 46 and 86 . 


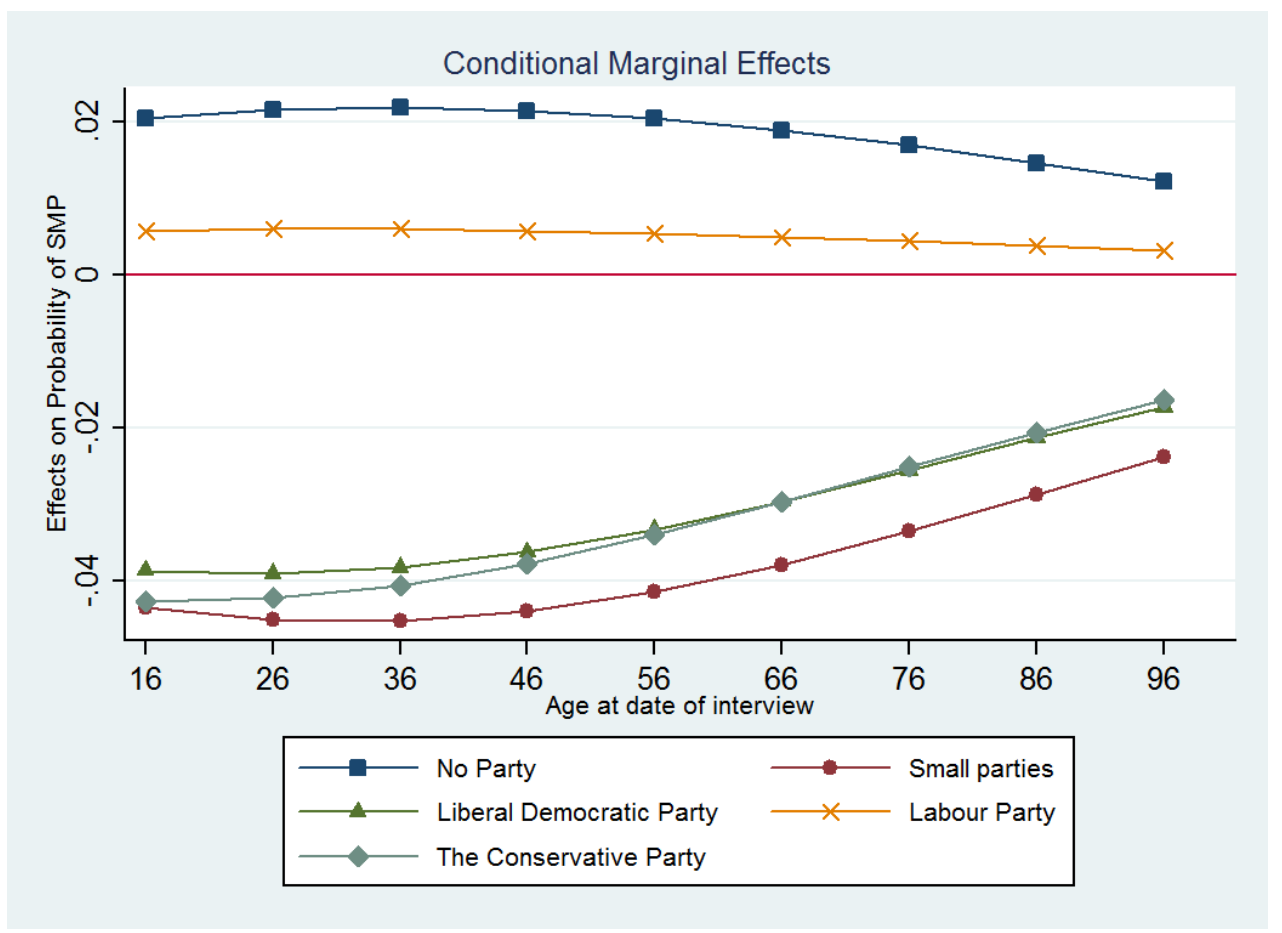

Figure 3. Conditional marginal effects of shift in political preferences - varied representative values

The figure displays the conditional marginal effects of a shift in political identity. The marginal effects are evaluated using varied characteristics as defined in the legend to Table III. Other variables are evaluated at their average values: age square, cohort and financial capability. For identification with the Conservative Party, the plotted marginal effects are significant at the $5 \%$ level among individuals aged 76 or below and at the $10 \%$ level for those aged above 76 . 